The Journal of Animal \& Plant Sciences, 30(6): 2020, Page: 1442-1464

ISSN (print): 1018-7081; ISSN (online): 2309-8694

\title{
EXPLORATION OF MEDICINAL PHYTO-DIVERSITY OF THE SEMI-ARID AREA IN PUNJAB PROVINCE, PAKISTAN
}

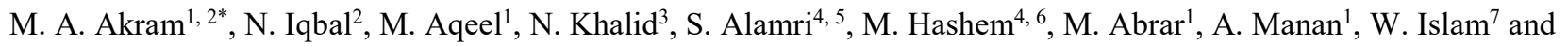 \\ A. Noman ${ }^{2 *}$ \\ ${ }^{1}$ School of Life Sciences, Lanzhou University, Lanzhou, Gansu Province, PR China \\ ${ }^{2}$ Department of Botany, Government College University, Faisalabad, Punjab, Pakistan ${ }^{3}$ Department of Botany, \\ Government College Women University, Sialkot, Pakistan \\ ${ }^{4}$ King Khalid University, College of Science, Department of Biology, Abha 61413, Saudi Arabia \\ ${ }^{5}$ Prince Sultan Ben Abdulaziz Center for Environmental and Tourism Research and Studies, King Khalid University, \\ Abha, Saudi Arabia \\ ${ }^{6}$ Assiut University, Faculty of Science, Botany Department, Assiut, 71516, Egypt \\ ${ }^{7}$ College of geography, Fujian Normal University, Fuzhou, China \\ *Corresponding Author’s Email: alinoman@gcuf.edu.pk; ynmadnan@gmail.com
}

$\begin{array}{ll}\text { Abbreviations:- } & \\ \text { FC: } & \text { The number of informants mentioning uses of a plant species } \\ \text { FL: } & \text { Fidelity Level } \\ \text { GIP: } & \text { Gastro-intestinal \& intestinal parasites } \\ \text { ICF: } & \text { Informant Consensus Factor } \\ \text { IK: } & \text { Indigenous Knowledge } \\ \text { IP: } & \text { Indigenous Plants } \\ \text { JI: } & \text { Jaccard Index } \\ \mathrm{N}_{\mathrm{t}}: & \text { The number of taxa or species used to cure that disease category } \\ \mathrm{N}_{\mathrm{ur}}: & \text { The total number of use report for each disease category } \\ \mathrm{RFC}: & \text { Relative Frequency Citation } \\ \text { ROP: } & \text { Rank Order Priority } \\ \text { RPL: } & \text { Relative Popularity Level } \\ \mathrm{UV}: & \text { Use Value }\end{array}$

\begin{abstract}
This is the first ethno-botanical study about the indigenous plants of district Faisalabad, Punjab-Pakistan. Main theme behind this study documents the existing ethno-medicinal data about local traditional herbal treatments. Overall, 300 local informants were interviewed from 22different locations of the district and collected data was analyzed by using different quantitative ethnobotanical tools. The 61 plants of 53 genera and 29 families be there found in use for 15 disease caused by microorganisms and contagious ones also. With reference to highest Use Value (UV), Ficus carica (0.83), Albizzia lebbeck (0.73) and Psidium guajava (0.71) were found the most used medicinal plant species in area. The $100 \%$ Fidelity Level (FL) was calculated for Acacia nilotica being used against gastro, respiratory, diabetics and hypertension. The highest Relative Frequency Citation (RFC) value was calculated for Citrus aurantifolia. The maximum Informant Consensus Factor (ICF) index was calculated for gastro and respiratory problems, fever, headache, and skin infection. The comparative study by calculating Jaccard Index (JI) with reported literature was shown that $8.18 \%$ resemblance and $12.81 \%$ distinction to earlier studies; however $79.01 \%$ medicinal uses of the reported species were documented the first time. The plants reported with high RPL index can be further analyzed for biochemical pharmaceutical and biotechnological screening.
\end{abstract}

Keywords: Biochemical, Diseases, Ethnobotanical study, Jaccard Index, Popular.

https://doi.org/10.36899/JAPS.2020.6.0166

Published online August 03,2020 


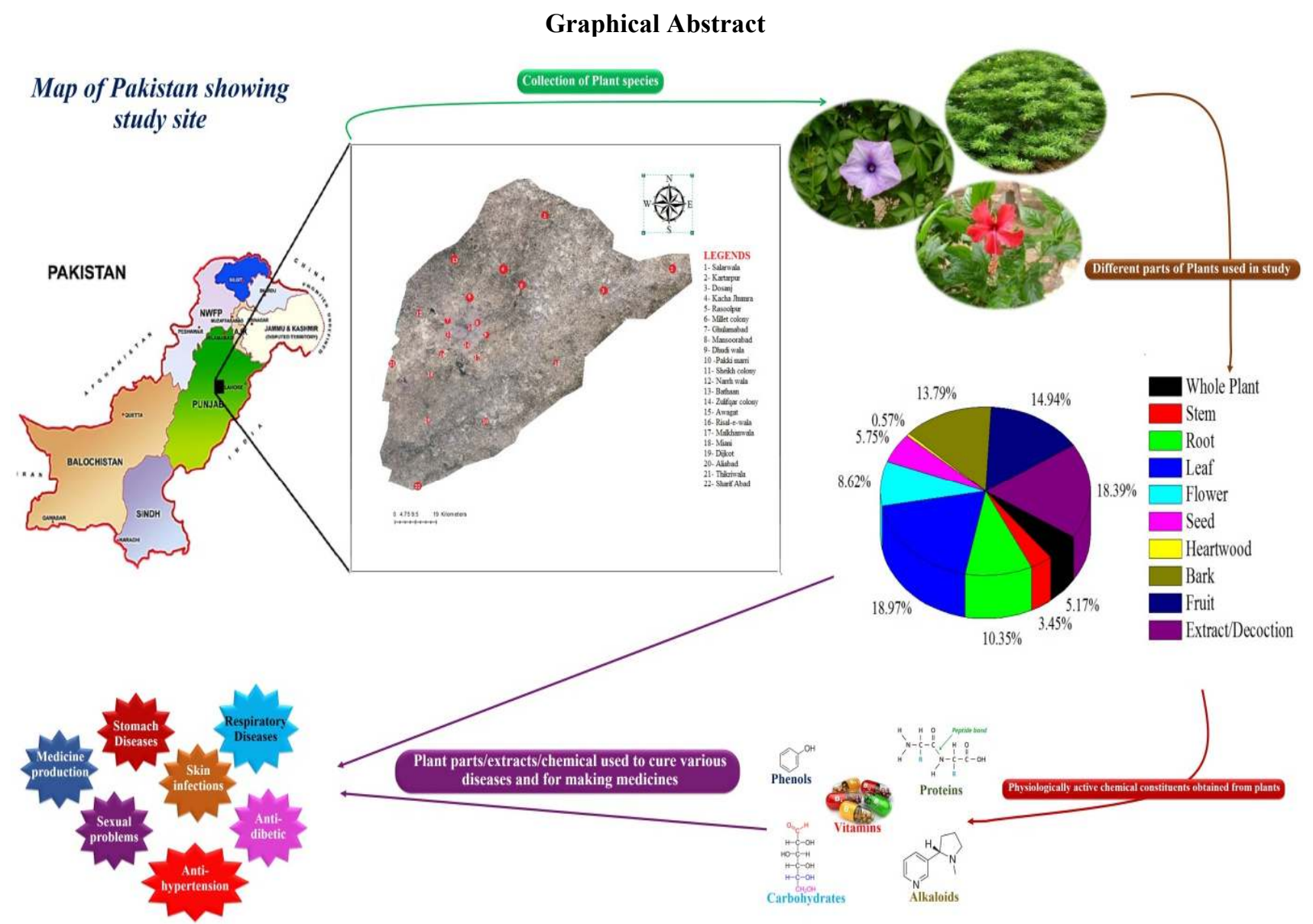

\section{INTRODUCTION}

The exclusive use of medicinal plants recipes and products by the people with faith to cure different diseases showed their reliance on medicinal plants (Islam et al., 2017; Shinwari and Qaiser 2011). Achievement of any curative system depends on the accessibility of suitable drugs on a sustainable source (Akram, 2020). Medicinal plants generally found in massive quantity particularly in the tropics, work on such plants prolong to concern researchers all over the world (Arulmozhi et al., 2007; Aqeel et al., 2019). The key goal of ethno pharmacological research be about to trace indigenous knowledge about plants and with profitable outcomes (Leporatti and Lattanzi 1994; Shinwari and Khan 2000). More than $80 \%$ of the populace in the third world countries depends merely on the therapeutic plants for conventional remedy. Natural remedies are cheaper and often the only medicines exist in distant countryside areas. Pakistan is gifted with amazing variety of natural flora with medicinal properties owing to varied climatic conditions (Shinwari 2010; Ali et al., 2016). Almost, 1500 plants which have suitable curative features stated in Pakistan. Eighty-four percent of populations prefer conventional medicines for their therapeutic desires (Hocking 1958). Presently, many synthetic medicines are also contrived by consuming biological constituent's resultant from medicinal flora. Ethno-botanical studies on the curative usages of plants by the natives are frequently notable; as an outcome, they offer new medicines from the herbal source (Noman et al., 2013; Amjad et al., 2017). Above 21,000 plants have been recorded for their medicinal uses in the world (Sarwat and Ahmad 2012). Approximately $20 \%$ out of the total plants present in the world are consumed for therapeutic treatments in humans (Khan et al., 2015; Hussain et al., 2012). The use of curative plants in customary health system changed the devotion and direction of scientists to ethno-botanical studies.

The district Faisalabad's soil is fertile, possessing a variety of plants with enormous healing properties. But phyto-diversity of this district remained unexplored. Keeping in view all these facts, the current study was planned to file the local therapeutic plants and indigenous data of this area to assess curative plants handed down by native community of district Faisalabad. We documented the local medicinal data about traditional herbal treatments for different diseases, including plant fragment(s) consumed and their application methods, 
way of grounding by using different ethno-botanical indices. Therefore, we have confidence that current study will act as glimmer of hope and aid to protect threatened plant species and as well as play probably noteworthy role to find the novel medicines.

\section{MATERIALS AND METHODS}

Description of study area: The current research was conducted in Faisalabad and it is the second largest district of province Punjab-Pakistan. District Faisalabad has an area of about 5,856 $\mathrm{km}^{2}\left(2,261 \mathrm{mi}^{2}\right)$.. Geographically, it is situated between $73^{\circ}$ to $74^{\circ}$ east longitudes and $30^{\circ}$ to $31.5^{\circ}$ north latitude, at 605 feet (at 180 meters) above the sea level. Faisalabad has semi-arid climate and weather of Faisalabad is intense with very slight rain fall and average annual rainfall is almost 375 millimeters (14.8 inch). The temperature range is $50^{\circ} \mathrm{C}$ in summer season (in month of June-July) to $04^{\circ} \mathrm{C}$ in winter season (in month of January-February). The river Chenab meets almost $80 \%$ of water requirements of the cultivated land.

Ethno-botanical survey, data collection, plants identification and preservation: We collected and document the indigenous knowledge (IK) and medicinal uses of local flora of district Faisalabad. The data was collected from 22 different sites of district (Figure 1). The fieldwork was based on frequent field tours, observations, (Malla et al., 2015) and individual interviews of 300 informants based on standard method and guidelines (Ishtiaq et al., 2012; Martin 2010; Chan et al., 2012).The ideal opportunity for field visits was chosen as per the existence cycle of the plants and their period of blossoming. The gathering, preparing and usage of the plant items by the neighborhood network were likewise remembered. The plants species were collected on various field visits from the investigation territory deliberately. The diverse accessible plant parts were collected like branches, bark, blooms, seeds and natural products and in addition conceivable.

All the 61 plants samples were collected with the assistance of local peoples during flowering stage pressed and preserved. Mostly information was documented during the field tours comprised informants bio data, local name(s) of used species, different parts of used plant, plant sources, preparation and administration measures, health disorders treated and others. The local herbalists (Hakims)/traditional healers and drug-sellers were also accessed for ratification of plants and their local medicinal uses. The photographs of reported plant species were caught with their blooms, leafy foods and in addition conceivable to confirm the identification (Figure 2).

Additional confirmation and consistency of collected information, plants scientific names and grouping were reconfirmed with the assistance of herbaria correlation, accessible ordered writing, Flora of West Pakistan, Flora of Punjab and Flora of Pakistan (Hocking, 1958). The gathered species were further dehydrated and safeguarded. Emphatically, the reported plants herbarium was preserved and plant sample slips were submitted in Department of Botany, Government College University Faisalabad. For further authentication of botanical names the international sites were used (www.theplantlist.org, and http://www.ars-grin.gov/cgibin/npgs/html/queries.pl). The local and scientific names of reported plant species and their ethno-medicinal usages were documented cautiously.

Quantitative analysis of collected data by using Ethnobotanical Indices: The collected and recorded data were expressed in MS excel sheets in the form of matrix citing botanical names of reported plant species, local names, locality of collection, family name, plant parts used, chemical constituents and ethno-medicinal uses (Table 1, 5). The ethnobotanical data was collected, calculated, integrated and analyzed as described and recommended (Verpoorte, 2002). The validity of data was checked by computing different ethnobotanical indices. The values of reported data were given in proportions and percentages.

Informants consensus factor (ICF): The informant consensus factor (ICF) value was ranged from 0 to 1 and ICF index was computed by utilizing the equation (Bhat et al., 2014; Heinrich et al., 1998)

$$
\mathrm{FIC}=\mathrm{N}_{\mathrm{ur}}-\mathrm{N}_{\mathrm{t}} /\left(\mathrm{N}_{\mathrm{ur}}-1\right) \ldots \ldots \ldots \ldots . . . . \text { (Equation 1) }
$$

Where, " $\mathrm{N}_{\text {ur }}$ " the aggregate number of utilization report for every disease class, " $\mathrm{N}_{\mathrm{t}}$ " the quantity of taxa or species utilized to cure particular disease class and " 1 " shows highest level of informant consensus.

Use value (UV): Use value, a technique that concludes the relative significance on plant uses, was also ascertained by utilizing the accompanying equation as described earlier (Phillips and Gentry 1993; Šavikin et al., 2013),

$\mathrm{UV}=\sum \mathrm{U}_{\mathrm{i}} / \mathrm{N} \ldots \ldots \ldots \ldots$ (Equation 2)

Where, "U" demonstrates the quantity of usages referred by informants for that plant species and "N" eludes the aggregate number of local witnesses/sources. High value of UV denotes that numerous use reports for that species and low value denotes less use reports stated by informants.

Relative Frequency of Citation (RFC): It was computed to assess the indigenous importance of a plant in study area. RFC was determined by utilizing the accompanying recipe as depicted earlier (Vitalini et al., 2013),

$\mathrm{RFC}=\mathrm{FC} / \mathrm{N} \quad(0<R F C<1) \ldots \ldots \ldots \ldots .($ Equation 3$)$ 
Where, "FC" is the quantity of witnesses specifying utilize of a plant and " $\mathrm{N}$ " is the aggregate number of witnesses/sources participating in survey.

Fidelity level (FL): It is calculated by using following formula as described previously

(Alexiades and Sheldon 1996),

$$
\text { FL }(\%)=\left(\mathrm{N}_{\mathrm{p}} / \mathrm{N}\right) \times 100 \ldots \ldots \ldots \ldots . \ldots(\text { Equation } 4)
$$

Where, "Np" the quantity of witnesses who cited the utilization of specific plant for a specific ailment and "N" aggregate number of sources citing to that species for a disease.

Relative popularity level (RPL): Briefly, an adjustment scale was presented, in which whole experienced plants were partitioned as "popular" and "unpopular". For popular plant species, RPL was self-assertively chosen by using rational approach as to 1.0 and " 1 " express the popularity of a plant species for main disease or disease category, while " 0 " express that no any disease or disease category cured by a plant. For unpopular plants, the RPL is under 1.0. RPL esteems might be ascertained for every particular species as per its location on graph. RPL was computed for singular species from the correlation between the quantity of witnesses who cited to a specific species and the normal number of usages individual species (Friedman et al., 1986).

Jaccard Index (JI): The JI is utilized to contrast the present ethnobotanical research information and earlier published medicinal plants data in different regions of Pakistan and also with different nation-states of the world. The JI was figured by utilizing the recipe portrayed previously (González-Tejero et al., 2008),

$$
\mathrm{JI}=\mathrm{c} \times \quad \begin{gathered}
100 \\
\mathrm{a}+\mathrm{b}-\mathrm{c}
\end{gathered} \quad \text { (Equation 5) }
$$

Where, "a" is reported quantity of plants of the present investigation territory, " $b$ " is earlier published number of plants in other different areas and "c" for common quantity of plants in the two zones.

Rank order priority (ROP): ROP is a correction factor that used to give the proper positioning of plants using diverse values of FL and RPL. ROP is evaluated by formula as elucidated previously (Friedman et al., 1986)

$$
\mathrm{ROP}=\mathrm{FL} \times \mathrm{RPL} \ldots(\text { Equation } 6)
$$

\section{RESULTS AND DISCUSSION}

Faisalabad city possess a variety of plants, having massive therapeutic value. In current research work we focused on point by point ethno-medicinal and photographic portrayal of collective plants. Total 61 plants belonging to 53 genera and 29 families were gathered and recognized (Table 1, 5). The observed plant types include trees, shrubs and herbs. Chief plant habit was tree (Table 1). It discloses from collected floral data that majority of the plant species belongs to Moraceae family (Figure 4). A part of local population cannot afford modern medicines due to high price. Therefore, plants are extensively used by them for treatment of the sicknesses. Different parts of plants such as leaf, root and seed and so on are used to treat multiple diseases and health disorders. The plants at some point indicate variety in their stuffs (for the most part constituents) with the difference in environmental conditions.

Gender based use of indigenous knowledge (IK), age and occupation: Mostly the males have more IK and are familiar about the use of medicinal plants. Males also graduated as herbalists (Hakims) and practiced as traditional healer or Hakim while there is lesser trend of females to learn formal education as herbalists. Females have commonly learned IK from their parents through daily life observations. Majority of individuals acknowledged to have applicable IK and were practicing as herbalists (Hakims) were above 50 years. Moreover, the socio-demographic data of informants are shown in Table 2 and literacy data in Table 3, respectively.

Species diversity, consumptions and its application: This study highlighted versatile uses of 61 species belong to 29 families to treat and cure human diseases. We studied and noted the typical usages of local wild type indigenous plant species. Basic information about indigenous plants (IP) was set systematically by family and species name, curative practices and chemical constituents (Table 5).

Results reveal that collected indigenous herbs are widely being utilized to treat many ailments by local community of this district. Our findings are in accordance with opinion of earlier workers reported the similar application of herbs, particularly as solution in Faisalabad and adjoining zones (Zereen et al., 2013). A few plants in Faisalabad district have also been observed in other districts of province. For example, Mangifera indica, Ficus religiosa, Jasminum sambac etc. have been reported in this district and in Hafizabad district (Umair et al., 2017). It is worth mentioning that the region had meager agriculture conveniences of valuable therapeutic plants and apparently facing risk from over exploitation like grazing and cutting. The public responsiveness about the sustainability and protection of these plant species is crucially significant to control extensive cutting and detrimental practice before many of these turn into nonexistent.

Plants parts used and extensively used plant part: Different fragments of therapeutic native flora were utilized as drug by the indigenous community of this district (Figure 3). Amid the dissimilar herbal parts foliage were maximum used to cure the illnesses tracked 
by bark, fruit, root, flower, whole plant, stem and heart wood. Our results are in agreement to the results of Panghal et al.,(2010) and Noman et al., (2013, 2017) who described that the foliage was frequently utilized to cure diseases. Contrarily, our results are not in consent to the opinion about which had tended that root was the most well-known utilized part for the treatment of different ailments (Cheikhyoussef et al., 2011; Teklehaymanot 2009).

Life form of collected medicinal flora: The life form of reported medicinal plants in district was observed and trees (31 species) were found to dominant plant form followed by shrubs (26 species) as well as herbs (4 species) (Table 1, Figure 5). Most prevailing plant families in district were found with species number as: Moraceae (8), Apocynaceae (5), Euphorbiaceae, Fabaceae, Mimosaceae, Myrtaceae, Verbenaceae (4) and rest of the families which denoted the less number of species are represented in Figure 4.

Informant consensus factor (ICF): ICF index expresses informer's consent on the therapeutic plant utilization, and estimates inconsistency in means of exploitation counter to described illnesses (Table 4). To calculate ICF value, diseases were organized into 15 kinds on the consumption basis. The ICF index, close to 1 depicts that species is very famous and used by a large number of local people of this district because of its authenticity about diseases. However, the value of ICF, close to 0 depicts reduced informers usage of a particular plant to cure described ailments. The maximum $77.05 \%$ reported plant species were used for the diseases related to gastrointestinal \& intestinal parasites (GIP), followed by respiratory problems, fever/headache, skin infection, cuts/wounds healing, muscular-skeletal problems/ rheumatism, sexual problems, weakness or dizziness, neurologic diseases, infection as well as inflammation, anti-diabetic, cardiovascular problems, kidney problems, snake bite/scorpion bite and anti-hypertensive (63.93, $39.34,27.87,24.59,22.95,21.31,19.67,18.03,16.39$, $11.48,9.84,8.20,6.56$ and $6.56 \%$ respectively). These findings figure out gastro-intestinal \& intestinal parasites (GIP) and respiratory problems dominant in the district. Our results are in agreement with records related to gastro-intestinal \& intestinal parasites (GIP) and respiratory problems reported by some earlier researchers (Noman et al., 2017; Revathi et al., 2013; Umair et al., 2017). However, Benarba (Benarba 2016) and Abdelhalim et al., (Abdelhalim et al., 2017) reported more and different plants to cure gastro-intestinal \&intestinal parasites (GIP) and respiratory problems. The ICF value for different 15 ailment categories was found that showed highest consensus (0.43) of plants for gastrointestinal \& intestinal parasites while least consensus (0.19) was found for muscular-skeletal problems/rheumatism. The results regarding average ICF value 0.30 is not in agreement with the previous research work accomplished in Pakistan (Bibi et al., 2014; Umair et al., 2017).

Use value (UV) and Relative frequency of citation (RFC): The RFC value substantiates the citation frequency of a therapeutic plant utilized to cure many ailments. The RFC value of reported plants ranged between 2 to $17 \%$ (Table 1). The uppermost RFC index was computed for Citrus aurantifolia (0.17) and lowest value (0.02) was calculated for Euphorbia royleana, Callistemon viminalis, and Psidium guajava. The said species were described by maximum local informers, hence showing high RFC. The RFC index helps to sort out the potentially reported plants species for further phytochemical analysis, pharmacological analysis and also use as reference in drug development.

The reported value of UV ranged from $0.07-0.83$ shows low to high quantity of usage stated by the local informers for a specific reported plant species. The highest UV was found for Ficus carica (0.83), Albizzia lebbeck (0.73) and Psidium guajava (0.71) and lowest for Ficus benjamine with UV of 0.07 (Table 1). This UV index shows extensive use of species having high UV and less accessibility and medicinal uses of species having low UV. The plant species with high UV can be recommended for further evaluation of their phytochemical and pharmacological analyses to ensure the presence of bioactive compounds (Ahmad et al., 2016). However, the UV index cannot exactly differentiate that a plant was utilized for a particular or several diseases (Musa et al., 2011). The UV index also related with various issues e.g., maintenance and conservation of plants having maximum UV index (Albuquerque et al., 2006). The plant species like Ficus carica, Albizzia lebbeck and Psidium guajava are most probable to suffer the highest cutting, picking and harvesting threat. The most important plants can be sorted out and distinguished through such research based studies to maintain and guarantee their use in the society.

Ficus carica is also widely used to cure inflammation, cancer (Mawa et al., 2013), gastric problems, urinary tract infection, respiratory, endocrine and for reproductive disorders (Badgujar et al., 2014). Mishra et al., (Mishra et al., 2010), reported that Albizzia lebbeck bark have anti-asthmatic, anti-anaphylactic properties and pods have analgesic, anxiolytic, antiinflammatory, anti-diarrheal activities and antispermatogenic effect (Farag et al., 2013; Sheyin et al., 2015). The Psidium guajava broadly studied for antimicrobial (Mendez et al., 2016), against diabetes (Joseph et al., 2016), anti-inflammatory (El-Ahmady et al., 2013), anti-tumor, anti-cancer (Ashraf et al., 2016), for diabetes, vomiting, diarrhea and dyslipidemias (Elias et al., 2017) and leaves aqueous extracts of Psidium guajava use for obesity and dyslipidemias (Simao et al., 2017). These 
outcomes ratify high UV and RFC index of above stated medicinal plants in district Faisalabad.

Fidelity level (FL): The FL of plants was calculated that started from 22.22 and ended at $100 \%$ (Table 6). The high \%age of fidelity level (FL) of a plant species shows the dominance of a particular health disorder in a locality and the exploitation of plant species by the peoples to cure it (Bibi et al., 2014; Malla et al., 2015). The 100\% FL was calculated in Acacia nilotica for gastric, respiratory, diabetics and hypertensive diseases. 85.71, 80.95, 78.38, and 73.08\% FL was found for Salvadora oleoides, Ficus religiosa, Calotropis procera and Lawsonia inermis against respiratory diseases, sexual disorders, rheumatism and anti-inflammatory, respectively.

Ali et al., 2012 evaluated anti-cancer, antiplatelet aggregator, anti-pyretic properties of Acacia nilotica a reported plant species showed 100\% FL (Ali et al., 2012) while (Farzana and Tharique 2014) reported Acacia nilotica for the treatment of bleeding diseases, prolapse and leucorrhoea.

Relative popularity level (RPL): The 300 local informants mentioned 61 plants species for medicinal use against 15 different categories of diseases. The 21 species (out of 61) got more consideration by informants, so proceed for further analysis and calculations. A plant species referred by 17 or further local informers measured as popular while below 17 was considered as unpopular plant species. The high RPL value of these species shows their worth, efficacy and the IK of local community about their medicinal use. Therefore, according to this criterion it was found that 9 plants cited by 17 informers or further were categorized for popular and 12 plants were mentioned very few to 16 informers were classified unpopular. Salvadora oleoides (Salvadoraceae), Ficus religiosa (Moraceae), Calotropis procera (Asclepiadaceae), Acacia nilotica (Mimosaceae), Lawsonia inermis (Lythraceae), Psidium guajava (Myrtaceae), Nerium oleander (Apocynaceae), Melia azedarach (Meliaceae) and Rosa indica (Rosaceae) were found the popular species in this district with 1.0 RPL value (Table 6). This is the earliest reference line study about IK of native community on the subject of utilization of these popular local indigenous plants (IP) species for specific diseases. The results of this study are in line with earlier studies about the eminence of ethnomedicinal plant species amid Bedouins of the desert (Friedman et al., 1986) and ethno-botanical studies of medicinal plants in Palestinian area. Alhagi maurorum and Tamarix aphylla were classified as unpopular species in above discussed studies because of their low RPL value.

Rank order priority (ROP): The ROP values were utilized to allocate an appropriate rank to plants having diverse fidelity levels. These RPL values were used as correction factor for the adjustment and settlement of FL. The RPL values of 21 most important reported plant species has been shown in Table 6. The ROP value above 50 only found for 9 plant species (Table 6). It is perhaps due to lack of awareness about indigenous knowledge (IK) or less popularity of traditional medicines among the peoples of this district. Acacia nilotica was extensively used plant species because of its ROP value was found 100 while the plant species Salvadora oleoides, Ficus religiosa, Calotropis procera, Lawsonia inermis, Psidium guajava, Nerium oleander, Melia azedarach and Rosa indica were found with notable ROP values $(86,81,78$, 73, 69, 63, 58 and 53 respectively). The ROP indexes reported by (Friedman et al., 1986; Umair et al., 2017) were comparable to the results and findings of the present study.

Jaccard index (JI): An evaluation of reported data by ethno-botanists from the different areas of Pakistan as well as other neighboring and international countries was executed by using the formula and method of Jaccard Index (JI). The original application data of 61 ethnomedicinal plant species in our present study was associated with 20 former ethno-botanical studies conducted and published from different areas of Pakistan and China Bangladesh, Namibia, Tanzania, Ethiopia, Algerian Sahara, Iraq, Iran, Afghanistan, India (Table 7). The highest JI value was calculated 18.75 , tracked by 14.96 and lowest JI value was found 0.50 , tracked by 0.81 . The present study data of 61 plant species of district Faisalabad showed similarity index of the compared information sorts from 20.75 to 0.71 and the deviation fraction ranges from 47.17 to 1.42 . The three highest values of similarity index was documented from Pakistan with the ethnobotanical studies of (Hussain et al., 2012), followed by (Umair et al., 2017) and (Qasim et al., 2014) with JI value 20.75, 20.00 and 16.67 respectively (Table 7) and the lowest was documented from the studies of (Alam et al., 2011) with JI value 0.71. The maximum level of similarity index was establish with the work of (Hussain et al., 2012), that shown some cultural, ethnic, environmental, geographical and vegetation similarity between Faisalabad and Mirpurkhas. While, the minimum level of similarity index was establish with work of (Alam et al., 2011) in Buner-Pakistan, it might be due to some ecological barriers and difference in indigenous knowledge (IK) that bring out geographical isolation of plant species and assortments in habitats and vegetation. Whereas, among countries the maximum similarity value was documented from Tanzania having JI value 16.13 and the lowest values of similarity index was found from China with JI value 1.16. Normally, traditional herbal practitioners shared indigenous knowledge (IK) with their own decedents and generations. The indigenous knowledge (IK) varies from one 
community to another due to social and cultural practices. It also differs with gender, age, origin and literacy level of persons cited indigenous knowledge (IK). This type of comparative ethnobotanical studies is very helpful to explore the important indigenous knowledge (IK) or information among communities of different regions and countries lead to find the new remedies for diseases.

Innovation and future influence: The current ethnobotanical study is first document to explore the indigenous knowledge (IK), uses and medicinal properties of 61 medicinal plant species in district Faisalabad utilized by the native community. The comparison of reported species with earlier studies related to medicinal plants described in various regions of Pakistan and in other neighboring countries as presented in the Table 7 to trace out the novelty innovation index. Almost, $8.18 \%$ therapeutic utilization of stated plants was identical, while $12.81 \%$ were distinct to earlier studies. However, 79.01\% medicinal uses of reported plant species were innovative in the current study.

Additionally, medicinal usages of plants described in different zones of Pakistan e.g. from Mirpurkhas Sindh Province of Pakistan displayed maximum similarity index with JI value 20.75 as compared to other areas of Pakistan. The collected ethnobotanical data from the district Faisalabad expose remarkable difference with regard to use of plant parts, method of verdant preparation and their consummation as published and stated from different areas of Pakistan and other countries.

Few of the newly reported and documented therapeutic uses and pertinent plants cited, consist of: Acacia nilotica (pneumonia), Albizzia lebbeck (leprosy), Alstonia scholaris (malaria), Calotropis procera (tuberculosis), Carissa carandas (anti-hypertensive), Dalbergia sissoo (leucoderma), Eucalyptus camaldulensis (dizziness), Ficus carica (kidney or bladder stone), Ficus religiosa (carbuncle), Mangifera indica (scabies), Melia azedarach (fever \& headache), Nerium oleander (cardiovascular diseases), Psidium guajava (cuts \& wounds healing), Punica granatum (jaundice), Ricinus communis (galactagogue), Rosa indica (semen secretion), Salvadora oleoides (snake biting/scorpion biting), Thevitia peruviana (rheumatism) and Zizyphus mauritiana (paralysis). The plants reported with new restorative, medicinal usages and high estimation of RPL could be contemplated advance for phytochemical analysis, to screen out the bioactive mixes and compounds, pharmacological analysis and also use as reference in drug development and to introduce novel drugs. 
Table 1. Presentation of plant parts used, life form, RFC value, UV value along with their distribution across the district Faisalabad.

\begin{tabular}{|c|c|c|c|c|c|c|c|c|c|c|c|c|c|}
\hline Name of Species & Common Name & Location & Habit & RFC & $\mathbf{U V}$ & WP & ST & RT & $\mathbf{L}$ & FL & SE & HW & B FR ED \\
\hline Acacia nilotica $L$. & Daisikikar & Gulfishan colony & & 0.07 & 0.48 & & & & & & & & \\
\hline AlbizzialebbeckBenth. & Shareen & Ayub colony & & 0.04 & 0.73 & & & & & & & & \\
\hline Alstonia scholaris $R . B r$. & Dita bark, Devil's tree & Sheikh colony & & 0.13 & 0.30 & & & & & & & & \\
\hline Azadirachta indica A. Juss. & Nimb, Neem & Gulfishan colony & & 0.09 & 0.21 & & & & & & & & \\
\hline Bombaxceiba Linn. & Simbal & Gulfishan colony & & 0.03 & 0.33 & & & & & & & & \\
\hline Bougainvillea spectabilisWilld. & Gate bale,Bougain bale & Ghulamabad & & 0.06 & 0.29 & & & & & & & & \\
\hline Callistemon viminalis G. Don. & Bottlebrush & Samanabad & & 0.02 & 0.20 & & & & & & & & \\
\hline Calotropis procera (Ait) R. Br. & Ak, Safaidak & Ghulamabad & & 0.08 & 0.50 & & & & & & & & \\
\hline Capparisaphylla Roth. & Delha & Millet colony & & 0.03 & 0.33 & & & & & & & & \\
\hline Carissa carandasAuct. & Karanda & Ayub colony & & 0.04 & 0.45 & & & & & & & & \\
\hline Cestrum nocturnum $L$. & Raatki rani & Risal-e-Wala & & 0.10 & 0.17 & & & & & & & & \\
\hline Citrus aurantifoliaSwingle. & Khagzilimun & Gulfishan colony & & 0.17 & 0.22 & & & & & & & & \\
\hline Cordiamyxa Linn. & Lasoorha & Ghulamabad & & 0.03 & 0.60 & & & & & & & & \\
\hline DalbergiasissooRoxb. ex DC. & Tahli, Shisham & Gulfishan colony & & 0.11 & 0.39 & & & & & & & & \\
\hline Durantarepens Linn. & Duranta & Samanabad & & 0.04 & 0.17 & & & & & & & & \\
\hline Eucalyptus camaldulensisDehnh. & Safaida & Sheikh colony & & 0.07 & 0.52 & & & & & & & & \\
\hline Eugenia jambolana Lam. & Jaman & Samanabad & & 0.09 & 0.22 & & & & & & & & \\
\hline Euphorbia royleanaBoiss. & Churee & Sheikh colony & & 0.02 & 0.67 & & & & & & & & \\
\hline Ficusbengalensis Linn. & Bargad & Dhudi wala & & 0.05 & 0.47 & & & & & & & & \\
\hline Ficus benjamine Linn. & Putrajanvi & Ayub colony & & 0.12 & 0.07 & & & & & & & & \\
\hline Ficus carica Linn. & Anjir & Ghulamabad & & 0.04 & 0.83 & & & & & & & & \\
\hline Ficus elastic Linn. & Rubber tree & Narrh wala & & 0.06 & 0.33 & & & & & & & & \\
\hline FicusinfectoriaRoxb. & Pilkhan & Pakki marri & & 0.07 & 0.29 & & & & & & & & \\
\hline FicusmacrophyllaDesf. ex Pers. & Bayfig & Ayub colony & & 0.10 & 0.17 & & & & & & & & \\
\hline Ficus religiosa Linn. & Bodhi, Peepal & Ghulamabad & & 0.04 & 0.67 & & & & & & & & \\
\hline Gmelinaphilippensis Linn. & Badhara & Samanabad & +2 & 0.02 & 0.17 & & & & & & & & \\
\hline Hibiscus rosa-sinensis Linn. & Shoe flower & Gulfishan colony & 4 & 0.13 & 0.18 & & & & & & & & \\
\hline Ipomoea cairica Sweet. & Messina & Sheikh colony & 米 & 0.04 & 0.36 & & & & & & & & \\
\hline Ipomoea carneaJacq. & Besharmibooti & Sheikh colony & *ै & 0.07 & 0.29 & & & & & & & & \\
\hline JasminumsambacAit. & Motiaa, Jasmine & Sheikh colony & $\sqrt{2}$ & 0.09 & 0.30 & & & & & & & & \\
\hline JatrophaintegerrimaJacq. & Jatropha & Ghulamabad & + & 0.03 & 0.44 & & & & & & & & \\
\hline
\end{tabular}




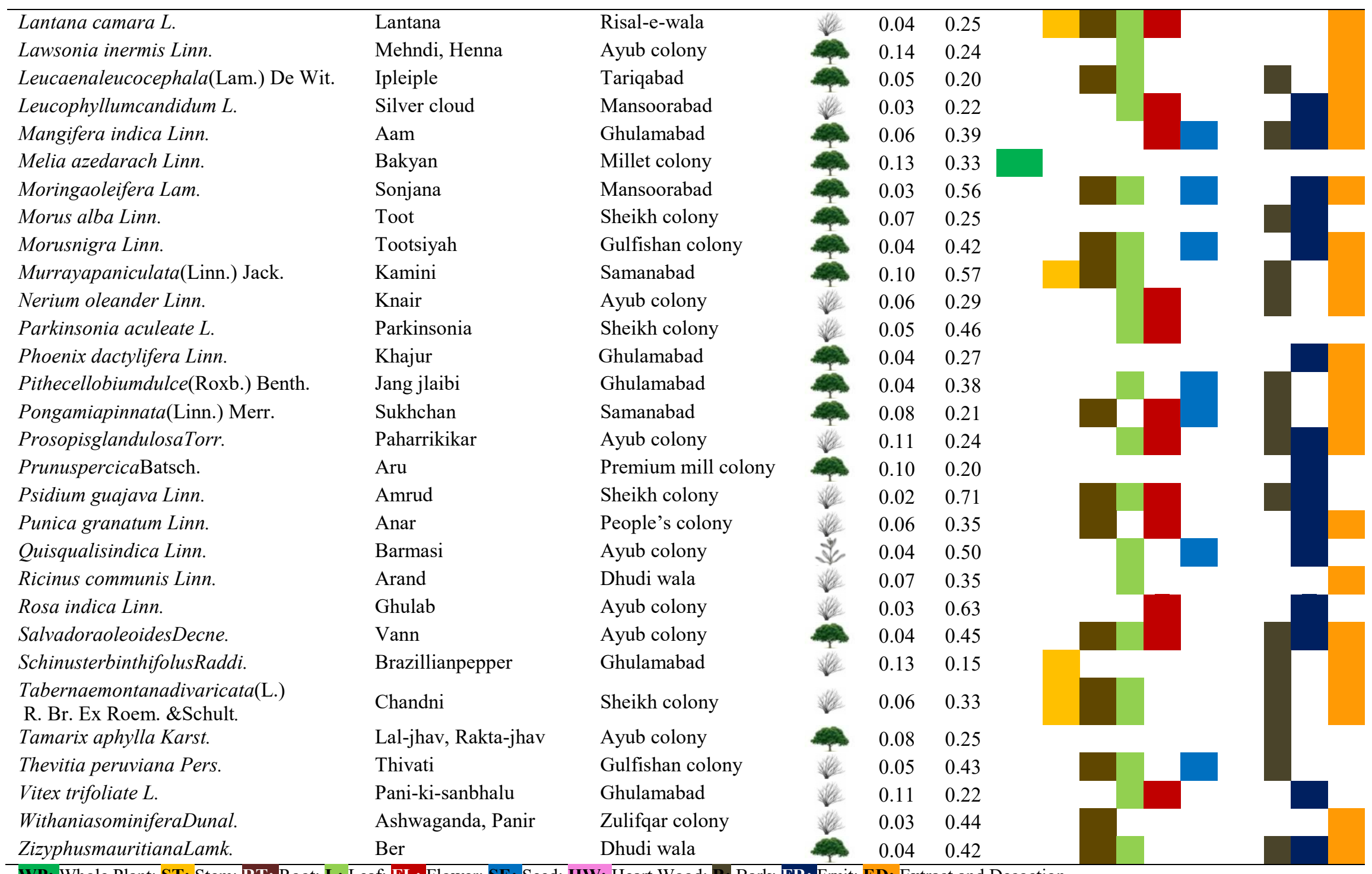

WP: Whole Plant; ST: Stem; RT: Root; L: Leaf; FL: Flower; SE: Seed; HW: Heart Wood; B: Bark; FR: Fruit; ED: Extract and Decoction

Plant habit: Tree, Shrub, Herb; RFC: Relative frequency citation; UV: Use value 
Table 2. Age range and gender ratio of informants from District Faisalabad.

\begin{tabular}{|c|c|c|c|c|c|}
\hline \multirow[b]{2}{*}{ Category No. } & \multirow{2}{*}{ Age Range } & \multicolumn{2}{|c|}{ Gender } & \multirow{2}{*}{ No. of persons } & \multirow[b]{2}{*}{ Percentage $(\%)$} \\
\hline & & Male & Female & & \\
\hline Herbalist/Hakims & Above 50 & 7 & 1 & 8 & 2.67 \\
\hline Youth & 21-30 & 28 & 2 & 30 & 10.00 \\
\hline Adult & $31-40$ & 39 & 16 & 55 & 18.33 \\
\hline Middle age & $41-50$ & 67 & 32 & 99 & 33.00 \\
\hline Senior & $51-60$ & 43 & 27 & 70 & 23.33 \\
\hline Old & $61-70$ & 21 & 5 & 26 & 8.67 \\
\hline \multirow[t]{2}{*}{ Very old } & Above 70 & 9 & 3 & 12 & 4.00 \\
\hline & Total & 214 & 86 & 300 & \\
\hline
\end{tabular}

Table 3. Educational ability of informants from District Faisalabad.

\begin{tabular}{lc}
\hline Education level & No. of individuals \\
\hline Illiterate & 113 \\
Primary & 57 \\
Middle & 73 \\
Secondary & 39 \\
University & 18 \\
Total & $\mathbf{3 0 0}$ \\
\hline
\end{tabular}

Table 4. Informant consensus factor (*ICF) of reported plant species against different disease categories.

\begin{tabular}{|c|c|c|c|c|c|}
\hline Disease Categories & Plant reported & $\begin{array}{c}\text { Use Reports } \\
\text { (Nur) }\end{array}$ & \%age of use reports & \%age of taxa & ICF \\
\hline Gastro-intestinal \& Intestinal parasites & 47 & 82 & 20.61 & 77.05 & 0.43 \\
\hline Fever and headache & 24 & 38 & 10.53 & 39.34 & 0.38 \\
\hline Muscular-skeletal problems/Rheumatism & 14 & 17 & 6.14 & 22.95 & 0.19 \\
\hline Weakness and dizziness & 12 & 19 & 5.26 & 19.67 & 0.39 \\
\hline Cuts and wounds Healing & 15 & 21 & 6.58 & 24.59 & 0.30 \\
\hline Respiratory problems & 39 & 51 & 17.11 & 63.93 & 0.24 \\
\hline Snake bite/Scorpion bite & 4 & 6 & 1.75 & 6.56 & 0.40 \\
\hline Cardiovascular problems & 6 & 9 & 2.63 & 9.84 & 0.38 \\
\hline Sexual problem & 13 & 17 & 5.70 & 21.31 & 0.25 \\
\hline Neurologic diseases & 11 & 14 & 4.82 & 18.03 & 0.23 \\
\hline Skin infection & 17 & 22 & 7.46 & 27.87 & 0.24 \\
\hline Infection and Inflammation & 10 & 15 & 4.39 & 16.39 & 0.36 \\
\hline Anti-diabetic & 7 & 9 & 3.07 & 11.48 & 0.25 \\
\hline
\end{tabular}




\begin{tabular}{lllll}
\hline Anti-hypertensive & 4 & 5 & 1.75 & \\
Kidney problems & 5 & 7 & 2.56 & \\
\hline
\end{tabular}

Table 5. Medicinal uses and physiologically active chemical constituentsof reported plant species in district Faisalabad.

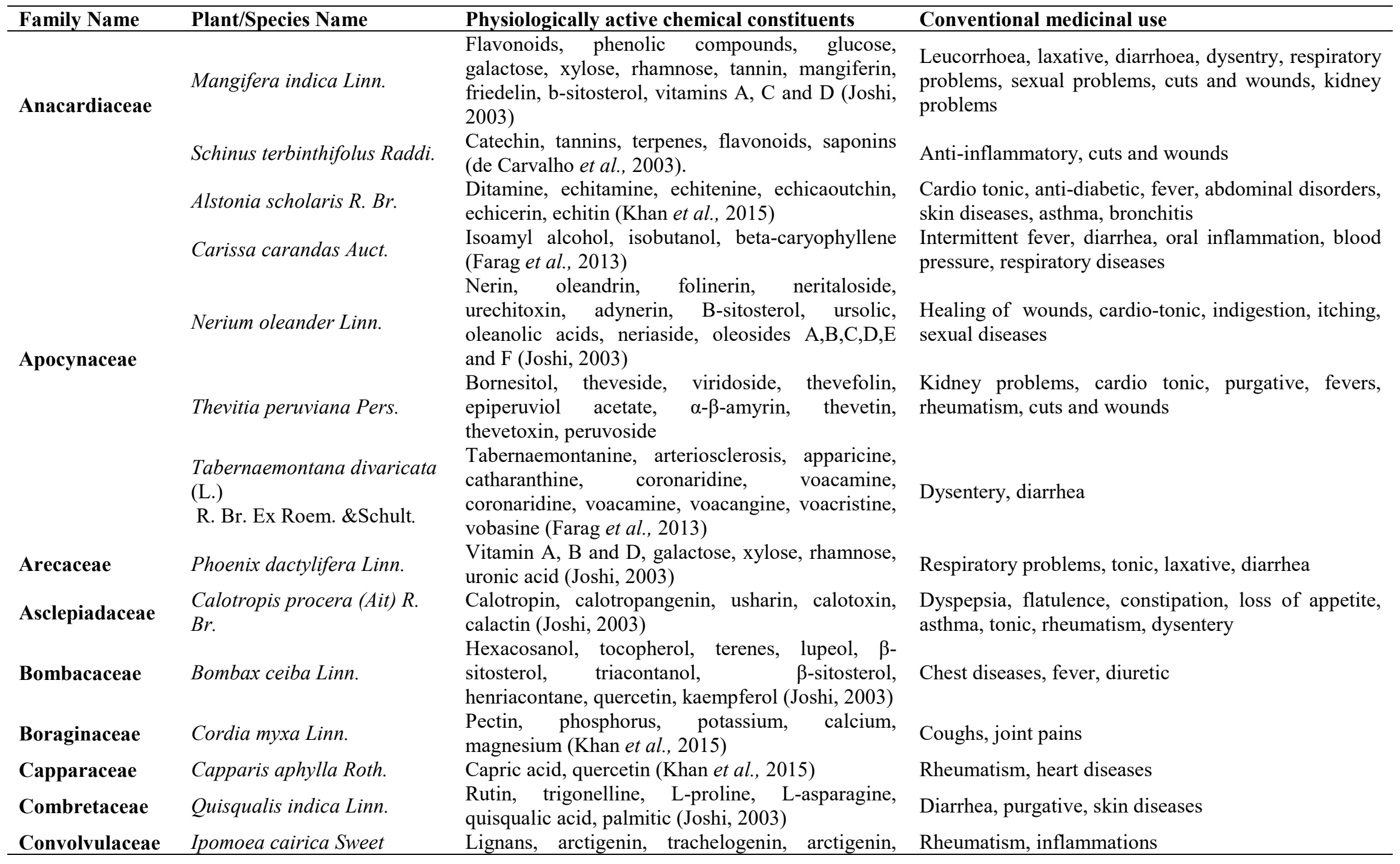




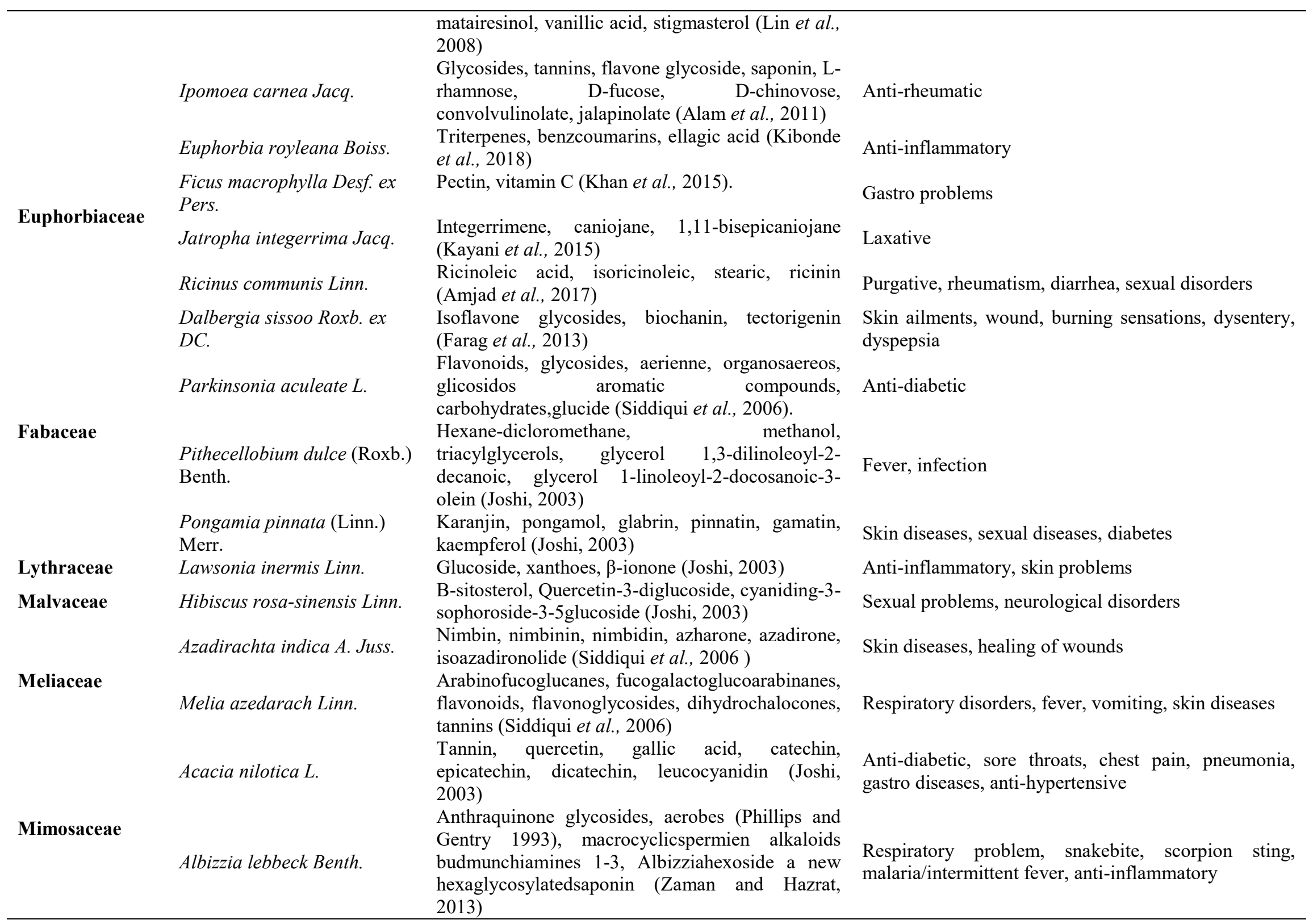




\begin{tabular}{|c|c|c|c|}
\hline & $\begin{array}{l}\text { Leucaena leucocephala } \\
\text { (Lam.) De Wit. }\end{array}$ & $\begin{array}{l}\text { Mimosine, glucosidequercetrin, hydrocyanic acid, } \\
\text { leucaenine, quercitrin, tannic acid (Zaman and } \\
\text { Hazrat, 2013) }\end{array}$ & Sexual problems \\
\hline & Prosopis glandulosa Torr. & $\begin{array}{l}\text { Prosopine, prosopinine, isoprosopinine, prosofrine, } \\
\text { prosofrinine, prosopol (Lin et al.,2008) }\end{array}$ & Rheumatism, scorpion sting, sexual problems \\
\hline & Ficus bengalensis Linn. & $\begin{array}{l}\text { Bengalenoside, friedelin, quercetin, } \beta \text {-sitosterol, } 3 \text { - } \\
\text { galactoside, rutin, taraxasteroltiglate (Joshi, 2003) }\end{array}$ & $\begin{array}{l}\text { Skin diseases, vaginal disorders, anti-inflammatory, } \\
\text { asthma, nervous disorders, rheumatism, anti-diabetic }\end{array}$ \\
\hline & Ficus benjamine Linn. & $\begin{array}{l}\text { Proteose, amino acid, tyrosin, enzyme cravin, } \\
\text { lipase, protease, pectose (Siddiqui et. al., 2006) }\end{array}$ & Cuts and wounds \\
\hline & Ficus carica Linn. & $\begin{array}{l}\text { Flavonoids, rutin, tannins, ketoses, coumarins, } \\
\text { psoralen, bergaptene, octacosane, valeric acids, } \\
\text { guaiacol (Amjad et al., 2017) }\end{array}$ & Laxative, kidney problems, fever, skin diseases, tonic \\
\hline & Ficus elastic Linn. & Tannin, silica, phosphoric acid (Khan et al., 2015) & Dysentery, respiratory problem \\
\hline \multirow[t]{4}{*}{ Moraceae } & Ficus infectoria Roxb. & $\begin{array}{l}\text { Flavonoids, flavonol O-glycosides (Greenham et. } \\
\text { al., 2007) }\end{array}$ & Vaginal diseases \\
\hline & Ficus religiosa Linn. & $\begin{array}{l}\text { Phytosterolins, } \beta \text {-sitosterol-D-glucoside, vitamin K } \\
\text { (Joshi, 2003) }\end{array}$ & Purgative, skin diseases, sexual diseases, asthma \\
\hline & Morus alba Linn. & $\begin{array}{l}\text { Mulberrin, mulberrochromene, morusin, } \\
\text { cyclomorusin, mulberranol, alboctalol (Joshi, } \\
\text { 2003) }\end{array}$ & Purgative, fever, respiratory diseases \\
\hline & Morus nigra Linn. & $\begin{array}{l}\text { Linoleic acid, myristic acid, glucose, fructose, } \\
\text { stigmasterol, } \beta \text {-sitosterol, extract, rutin, carotene, } \\
\text { vitamin B and C, pectin (Khambay et. al., 1999) }\end{array}$ & $\begin{array}{l}\text { Sexual weakness, diarrhea, ulcerated } \\
\text { intestine,pharyngitis }\end{array}$ \\
\hline \multirow[t]{2}{*}{ Moringaceae } & Moringa oleifera Lam. & $\begin{array}{l}\text { Vitamin C, benzyl-isothiocyanate (Dayrit et. al., } \\
\text { 1990) }\end{array}$ & $\begin{array}{l}\text { Anti-rheumatic, anti-inflammatory, snake bite and } \\
\text { scorpion sting }\end{array}$ \\
\hline & $\begin{array}{l}\text { Callistemon viminalis } G \text {. } \\
\text { Don. }\end{array}$ & Viminadione A-B (Khambay et. al., 1999) & Heart diseases \\
\hline \multirow[t]{3}{*}{ Myrtaceae } & $\begin{array}{l}\text { Eucalyptus camaldulensis } \\
\text { Dehnh. }\end{array}$ & $\begin{array}{l}\text { Betulinic acid, oleanolic acid, ursolic acid, beta- } \\
\text { phellandrene, p-cymene, cryptone (Siddiqui et. al., } \\
\text { 2006) }\end{array}$ & Coughs, throat ailments, diarrhea, dysentery, tonic \\
\hline & Eugenia jambolana Lam. & $\begin{array}{l}\text { Jambolin, ellagic acid, tannin, gallic acid, acetyl } \\
\text { oleanolic acid, kaempferol, myricetin (Joshi, 2003) }\end{array}$ & Dysentery, diarrhea, diabetes, cough and asthma \\
\hline & Psidium guajava Linn. & $\begin{array}{l}\text { Galacturonic acid, rhamnose, } \beta \text {-sitosterol, maslinic } \\
\text { acid, guijavalic acid, leucocyanidin (Joshi, 2003) }\end{array}$ & $\begin{array}{l}\text { Vitamin C, tonic, wounds, vomiting, diarrhea, } \\
\text { respiratory problems }\end{array}$ \\
\hline Nyctaginaceae & $\begin{array}{l}\text { Bougainvillea spectabilis } \\
\text { Willd. }\end{array}$ & $\begin{array}{l}\text { Ethylene, malondialdehyde, superoxide dismutase } \\
\text { (Kayani et al., 2015) }\end{array}$ & Infections \\
\hline Oleaceae & Jasminum sambac Ait. & Pyridine, nicotinate derivatives (Joshi, 2003) & Insanity, anti-hyperstensive \\
\hline Punicaceae & Punica granatum Linn. & $\begin{array}{l}\text { Pelletierine, isopelletierine, pseudopelletierine, } \\
\text { methyl-isopelletierine, sorbitol, mannitol, glucose, } \\
\text { fructose, sucrose, maltose, isoquercetin, vitamin C }\end{array}$ & Fever, cough, bronchitis, vomiting, diarrhea, tonic \\
\hline
\end{tabular}




\begin{tabular}{|c|c|c|c|}
\hline & & (Lakhdari et al., 2016) & \\
\hline Rhamnaceae & Zizyphus mauritiana Lamk. & $\begin{array}{l}\text { Leucocyanidin, leucopelargonidin, betulinic, } \\
\text { ceabothic acid, rutin (Joshi, 2003) }\end{array}$ & Fever, diarrhea, laxative, kidney problems \\
\hline \multirow{2}{*}{ Rosaceae } & Prunus percica Batsch. & $\begin{array}{l}\text { Hentriacontane, hentriacontanol, } \beta \text {-sitosterol, } \\
\text { ursolic acid, multinoside-A, kaempferol-3- } \\
\text { rhamnoside, quercetine (Joshi, 2003) }\end{array}$ & Cough, chronic bronchitis, vomiting \\
\hline & Rosa indica Linn. & $\begin{array}{l}\text { Anthocyanins, hydroxylations, epoxidations, } \\
\text { epoxide, ellagitannins (Cheikhyoussef et al., } \\
\text { 2011). }\end{array}$ & $\begin{array}{l}\text { Healing of wounds, fevers, sexual problems, laxative, } \\
\text { tonic }\end{array}$ \\
\hline \multirow[t]{2}{*}{ Rutaceae } & Citrus aurantifolia Swingle & $\begin{array}{l}\text { Citral, hesperidin, nobiletin, citromitin, vitamin B, } \\
\text { vitamin C, citric acid, synephrine (Amjad et al., } \\
\text { 2017) }\end{array}$ & Gastro problems \\
\hline & $\begin{array}{l}\text { Murraya paniculata (Linn.) } \\
\text { Jack. }\end{array}$ & Murrayin, scopolin (Lakhdari et al., 2016) & Respiratory diseases, cuts, diarrhea, dysentery \\
\hline Salvadoraceae & Salvadora oleoides Decne. & $\begin{array}{l}\text { Salvadorine, trimethylamine, phosphoric } \\
\text { anhydride (Khan et al., 2015) }\end{array}$ & $\begin{array}{l}\text { Purgative, constipation, fevers, snake-bite, asthma, } \\
\text { cough }\end{array}$ \\
\hline $\begin{array}{l}\text { Scrophulariacea } \\
\text { e }\end{array}$ & Leucophyllum candidum L. & $\begin{array}{l}\text { Diayangambin, epiyangambin, diasesartemin, } \\
\text { epiashantin (Shahat et al., 2005) }\end{array}$ & Gastro disorders \\
\hline \multirow[b]{2}{*}{ Solanaceae } & Cestrum nocturnum $L$. & $\begin{array}{l}\text { Spirostanolsaponin, furostanolsaponin, pseudo- } \\
\text { furostanolsaponin (Maryo et al., 2015) }\end{array}$ & Neural disorders \\
\hline & Withania sominiferaDunal. & $\begin{array}{l}\text { Withaferine A-B, } 3 \alpha \text {-tigloxytropine, cusohygrine, } \\
\text { anaferine, anahygrine, choline, visamine (Lakhdari } \\
\text { et al., 2016) }\end{array}$ & Rheumatism, nervous disorders, sexual problems \\
\hline Tamaricaceae & Tamarix aphylla Karst. & Tannic acid, dextrin (Khan et al., 2015) & Eczema, respiratory diseases \\
\hline \multirow{4}{*}{ Verbenaceae } & Duranta repens Linn. & $\begin{array}{l}\text { Phenylethanoid glycoside acteoside, } \\
\text { iridoidlamiide, saponin pseudo-ginsenoside } \\
\text { (Shahat } \text { et al., 2005) }\end{array}$ & Heart problems \\
\hline & Gmelina philippensis Linn. & Glucoside (Khan et al., 2015) & Gastro disorders \\
\hline & Lantana camara $L$. & $\begin{array}{l}\text { Palmitic acid, stearic acid, germacrene-D, } \\
\text { lantanoside, lantanone, lancamaric acid, } \\
\text { camarolide (Shahat } \text { et al., 2005) }\end{array}$ & $\begin{array}{l}\text { Blood pressure, asthma, bronchiectasis, arterial } \\
\text { hypertension, fever }\end{array}$ \\
\hline & Vitex trifoliate L. & Alkaloids (Lakhdari et al., 2016) & Rheumatism, headache \\
\hline
\end{tabular}

Table 6. Most vital and utilized plant species of the study area along with FL, RPL and ROP.

\begin{tabular}{|c|c|c|c|c|c|c|c|}
\hline Sr. No. & Name of Species & $\mathbf{N}_{\mathbf{P}}$ & $\mathbf{N}$ & NA & FL (\%) & RPL & ROP \\
\hline 1 & Salvadora oleoides Decne. & 42 & 49 & 9 & 85.71 & 1.00 & 86 \\
\hline 2 & Ficus religiosa Linn. & 34 & 42 & 5 & 80.95 & 1.00 & 81 \\
\hline 3 & Calotropis procera (Ait) R. Br. & 29 & 37 & 10 & 78.38 & 1.00 & 78 \\
\hline 4 & Acacia nilotica $L$. & 35 & 35 & 7 & 100.00 & 1.00 & 100 \\
\hline
\end{tabular}




\begin{tabular}{|c|c|c|c|c|c|c|c|}
\hline 5 & Lawsonia inermis Linn. & 19 & 26 & 3 & 73.08 & 1.00 & 73 \\
\hline 6 & Psidium guajava Linn. & 18 & 26 & 7 & 69.23 & 1.00 & 69 \\
\hline 7 & Nerium oleander Linn. & 15 & 24 & 5 & 62.50 & 1.00 & 63 \\
\hline 8 & Melia azedarach Linn. & 11 & 19 & 3 & 57.89 & 1.00 & 58 \\
\hline 9 & Rosa indica Linn. & 9 & 17 & 6 & 52.94 & 1.00 & 53 \\
\hline 10 & Punica granatum Linn. & 9 & 16 & 3 & 56.25 & 0.76 & 43 \\
\hline 11 & Ficus carica Linn. & 7 & 15 & 4 & 46.67 & 0.71 & 33 \\
\hline 12 & Mangifera indica Linn. & 5 & 15 & 7 & 33.33 & 0.71 & 24 \\
\hline 13 & Carissa carandas Auct. & 3 & 13 & 6 & 23.08 & 0.62 & 14 \\
\hline 14 & Azadirachta indica A. Juss. & 5 & 13 & 4 & 38.46 & 0.62 & 24 \\
\hline 15 & Ricinus communis Linn. & 4 & 13 & 4 & 30.77 & 0.62 & 19 \\
\hline 16 & Dalbergia sissoo Roxb. ex DC. & 6 & 12 & 9 & 50.00 & 0.57 & 29 \\
\hline 17 & Albizzia lebbeck Benth. & 4 & 9 & 5 & 44.44 & 0.43 & 19 \\
\hline 18 & Thevitia peruviana Pers. & 2 & 9 & 4 & 22.22 & 0.43 & 10 \\
\hline 19 & Eucalyptus camaldulensis Dehnh. & 4 & 8 & 6 & 50.00 & 0.38 & 19 \\
\hline 20 & Alstonia scholaris R. Br. & 3 & 7 & 3 & 42.86 & 0.33 & 14 \\
\hline 21 & Zizyphus mauritiana Lamk. & 1 & 4 & 3 & 25.00 & 0.19 & 5 \\
\hline
\end{tabular}

Np: No. of informants who reported use of species; N: number of total informants, NA: Number of ailments; FL: Fidelity level, RPL: Relative popularity level, ROP: Rank order priority

Table 7. The comparison of present study with earlier studies at the regional, national, and global scales.

\begin{tabular}{|c|c|c|c|c|c|c|c|c|c|c|}
\hline $\begin{array}{l}\text { Sr. } \\
\text { No. }\end{array}$ & Previous study area & References & $\begin{array}{c}\text { Total } \\
\text { documente } \\
\text { d species } \\
\text { in } \\
\text { previous } \\
\text { study }\end{array}$ & $\begin{array}{c}\text { Total } \\
\text { documente } \\
\text { d species in } \\
\text { present } \\
\text { study }\end{array}$ & $\begin{array}{c}\text { Simila } \\
\text { r use } \\
\text { of } \\
\text { plant }\end{array}$ & $\begin{array}{c}\text { Dissimila } \\
\mathbf{r} \text { use of } \\
\text { plant }\end{array}$ & $\begin{array}{c}\text { Plants } \\
\text { commo } \\
\text { n in } \\
\text { both } \\
\text { areas }\end{array}$ & 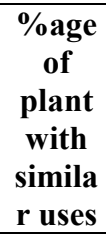 & $\begin{array}{l}\text { \%age of } \\
\text { plants } \\
\text { with } \\
\text { dissimila } \\
\text { r uses }\end{array}$ & $\begin{array}{c}\text { Jaccar } \\
\text { d Index } \\
\text { (JI) }\end{array}$ \\
\hline 1 & Buner, Pakistan & (Alam et al., 2011) & 141 & 61 & 1 & 2 & 1 & 0.71 & 1.42 & 0.50 \\
\hline 2 & Chaoshan, Guangdong, China & (Chan et al., 2012) & 86 & 61 & 1 & 5 & 2 & 1.16 & 5.81 & 1.38 \\
\hline 3 & Coastal areas of Pakistan & (Qasim et al., 2014) & 54 & 61 & 9 & 11 & 9 & 16.67 & 20.37 & 8.49 \\
\hline 4 & Fars, Iran & (Dolatkhahi et al., 2014) & 85 & 61 & 3 & 11 & 5 & 3.53 & 12.94 & 3.55 \\
\hline 5 & Guldara, Kabul, Afghanistan & (MH and Hamdam) & 68 & 61 & 2 & 5 & 2 & 2.94 & 7.35 & 1.57 \\
\hline 6 & Hafizabad,Punjab, Pakistan & (Umair et al., 2017) & 85 & 61 & 17 & 27 & 19 & 20.00 & 31.76 & 14.96 \\
\hline 7 & Kel,Neelum Valley, AK,Pakistan & (Ahmad et al., 2017) & 50 & 61 & 2 & 3 & 1 & 4.00 & 6.00 & 0.91 \\
\hline 8 & Kembatta, Southern Ethiopia & (Maryo et al., 2015) & 145 & 61 & 2 & 10 & 4 & 1.38 & 6.90 & 1.98 \\
\hline 9 & KeraniganjUpazila, Bangladesh & (Amirunnesa et al., 2018) & 10 & 61 & 1 & 3 & 1 & 10.00 & 30.00 & 1.43 \\
\hline 10 & Makran coast, Pakistan & (Noman et al., 2017) & 40 & 61 & 5 & 14 & 6 & 12.50 & 35.00 & 6.32 \\
\hline 11 & Malakand, KPK, Pakistan & (Zaman and Hazrat, 2013) & 40 & 61 & 6 & 12 & 5 & 15.00 & 30.00 & 5.21 \\
\hline 12 & Mbeya region, Tanzania & (Kibonde et al., 2018) & 31 & 61 & 5 & 6 & 4 & 16.13 & 19.35 & 4.55 \\
\hline 13 & Mirpurkhas, Sindh, Pakistan & (Hussain et al., 2012) & 53 & 61 & 14 & 21 & 18 & 26.42 & 39.62 & 18.75 \\
\hline
\end{tabular}




\begin{tabular}{|c|c|c|c|c|c|c|c|c|c|c|}
\hline 14 & Nellore, Andhra Pradesh, India & (Sasidhar et al., 2016) & 41 & 61 & 2 & 10 & 4 & 4.88 & 24.39 & 4.08 \\
\hline 15 & Northern areas of Pakistan & (Khan et al., 2015) & 51 & 61 & 2 & 2 & 1 & 3.92 & 3.92 & 0.91 \\
\hline 16 & Oshikoto region, Namibia & (Cheikhyoussef et al., 201 & 61 & 61 & 1 & 3 & 1 & 1.64 & 4.92 & 0.83 \\
\hline 17 & OuedRigh, Algerian Sahara & (Lakhdari et al., 2016) & 53 & 61 & 2 & 6 & 2 & 3.77 & 11.32 & 1.79 \\
\hline 18 & Sheikupura, Pakistan & (Zahoor et al., 2017) & 96 & 61 & 14 & 33 & 13 & 14.58 & 34.38 & 9.03 \\
\hline 19 & Sulaymaniyah, Kurdistan, Iraq & (Ahmed, 2016) & 63 & 61 & 1 & 2 & 1 & 1.59 & 3.17 & 0.81 \\
\hline 20 & Western Himalayan, Pakistan & $(\mathrm{Haq}, 2012)$ & 172 & 61 & 13 & 22 & 11 & 7.56 & 12.79 & 4.95 \\
\hline
\end{tabular}

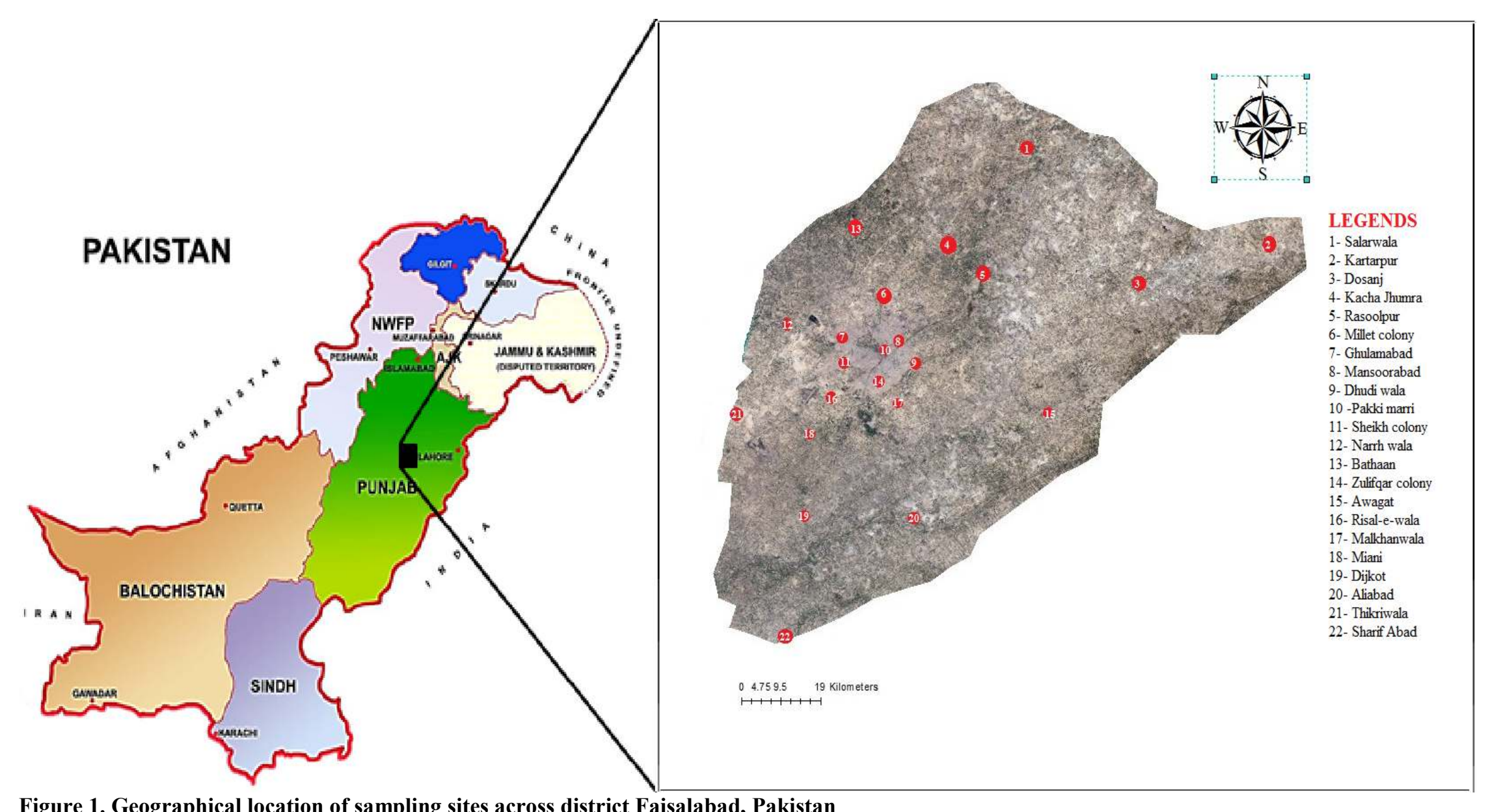

Figure 1. Geographical location of sampling sites across district Faisalabad, Pakistan 

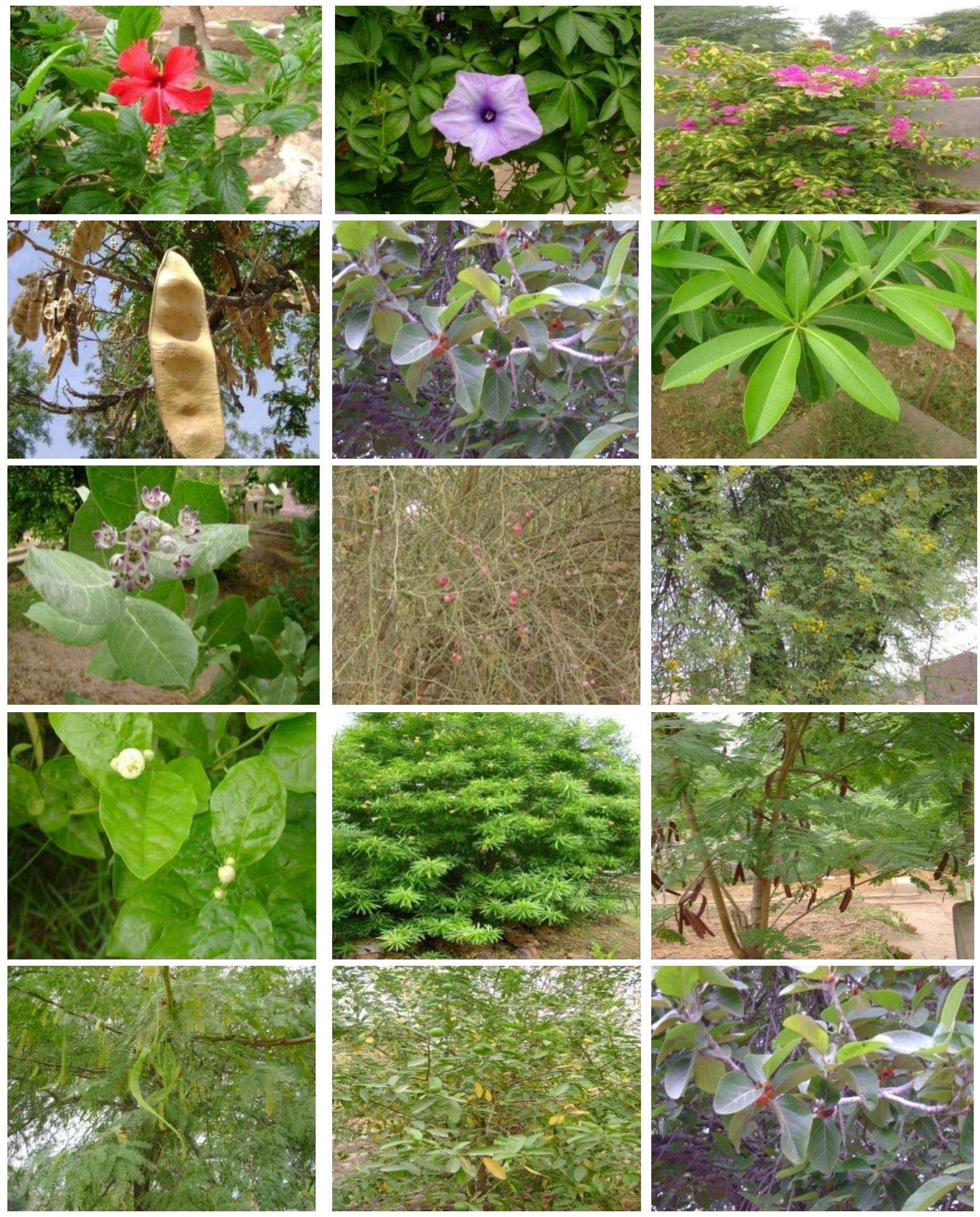

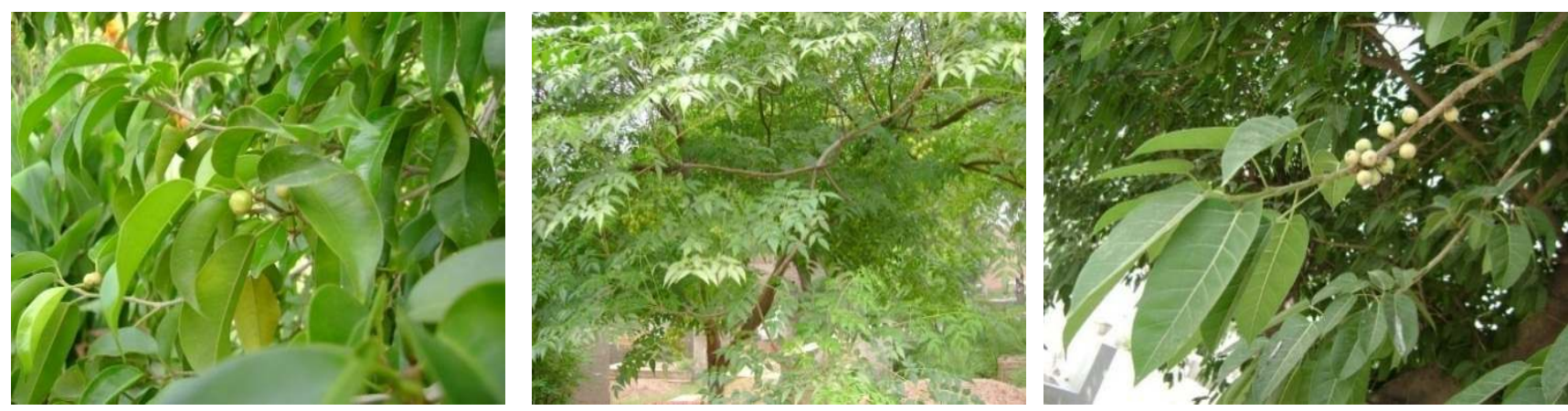

Figure 2. Photographic representation of Medicinal flora of Faisalabad district
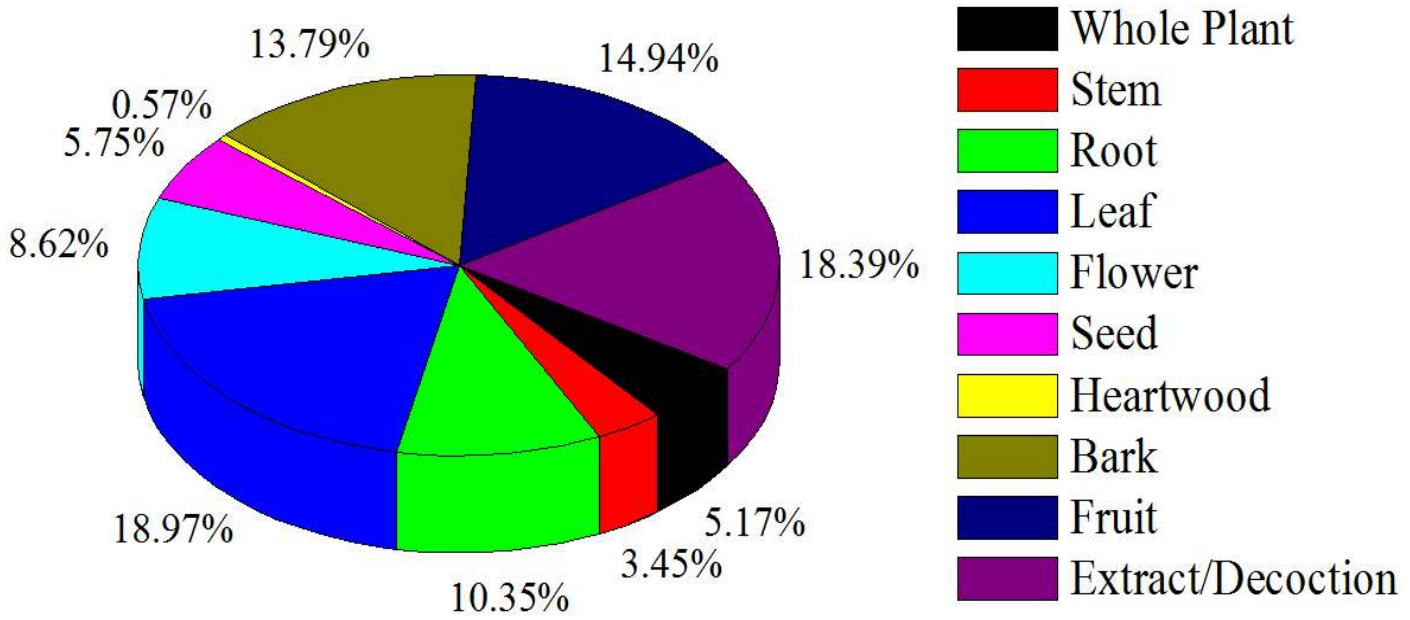

Figure 3. Graphical representation of plant parts used (\%age)

\section{Distribution of reported species in different families}

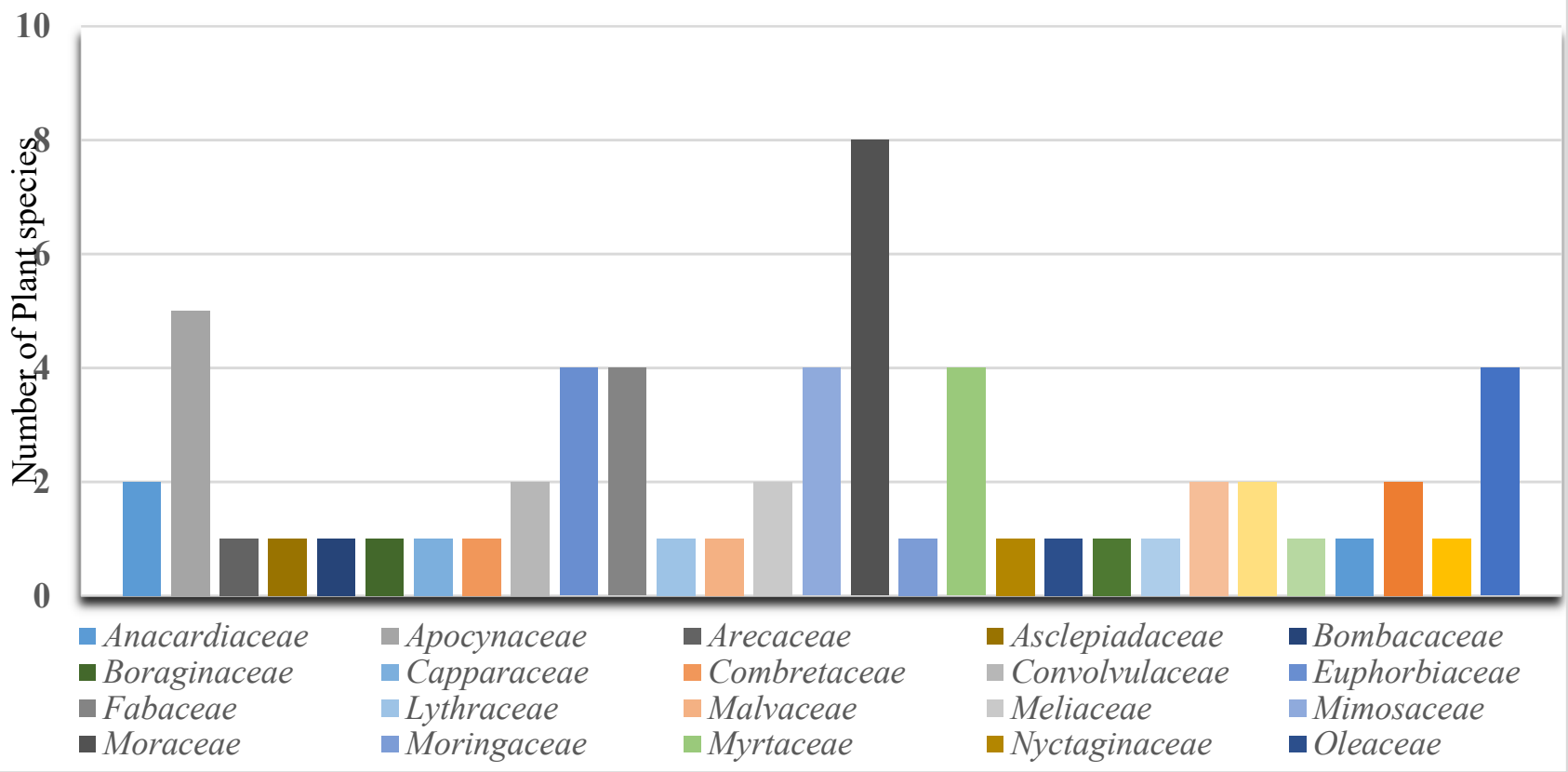

Figure 4. Graphical expression of reported species in families of Faisalabad district 


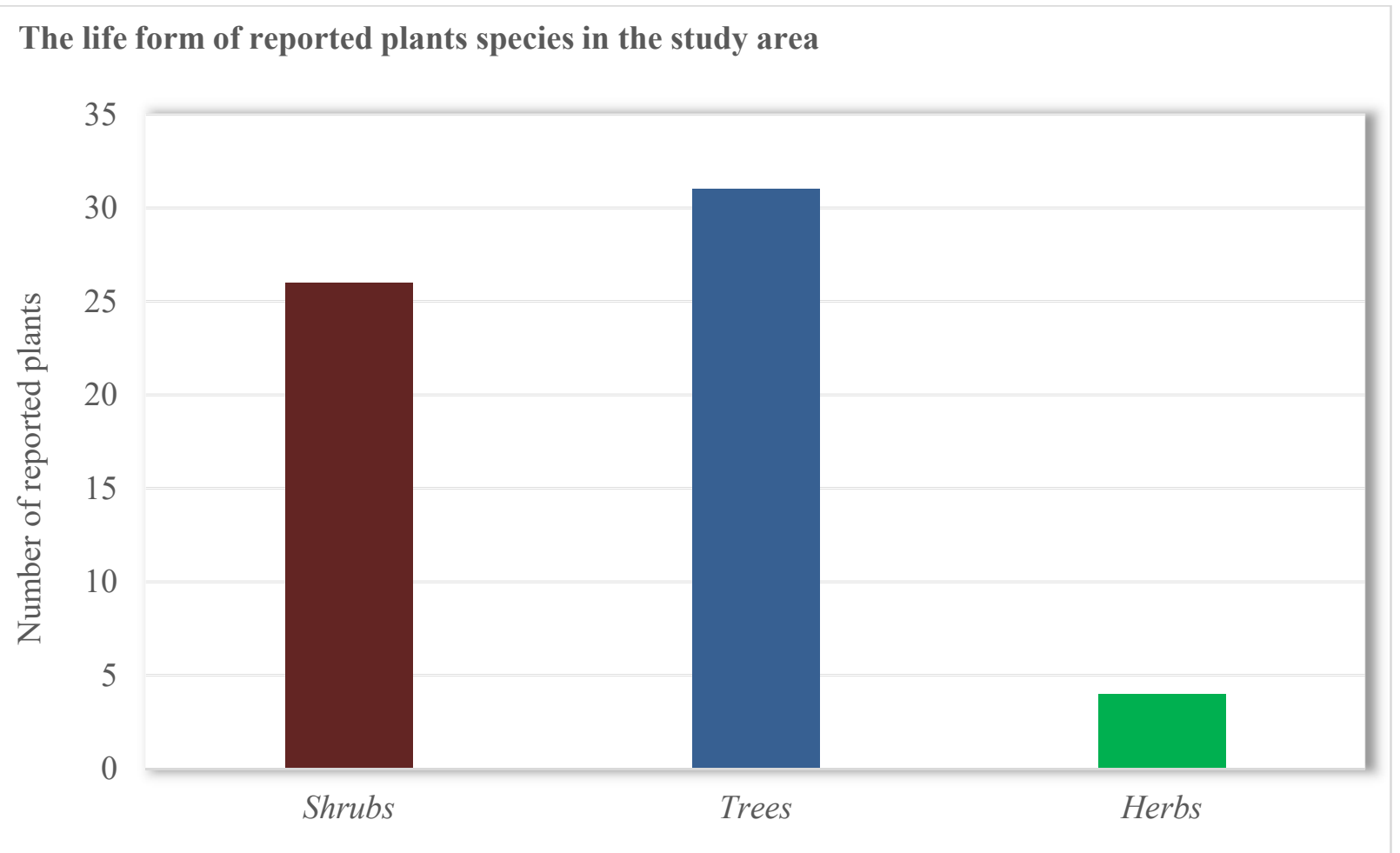

Figure 5. The life form of reported plants species in the study area

Conclusions: The current study reflects reliance of the natives of Faisalabad district on different medicinal plant species and utilized reported indigenous plant species to treat different diseases and to meet their medicinal needs. This ethno-botanical study is first document of district Faisalabad and indigenous knowledge (IK) has equipped us with the innovative ethno-medicinal data to make undocumented information available. The native community still trusts on traditional ethno-medicine and indigenous plants (IP) in spite of the modern health systems and specific drugs based on customary formulae and methods. Our findings offer reference line indigenous information to link the customary ethno-medicinal practitioners and scientific societies for preparing novel medicines. This ethnobotanical information is of substantial worth for conservatory policies and ministerial executives for ecological administration of ethno-medicinal flora at risk owing to haphazard urbanization, habitat loss and over exploitation. Extra exertions and exploration on sustainable utilization, conservation, marketing and management, ethnopharmacology and ethnobotany are vital to expose the wealth and prospective of ethno-medicinal flora of Pakistan. Hence the popular plants species must be anticipated thorough biochemical and pharmacological investigation for bioactive compounds, in vivo/in vitro biotic actions, which may be is a way of discover a novel and likely medicines. It will be a great contribution in the field of pharmacology and these medicinal plants be used at commercial level in medicinal or in a pharmaceutical industry for the human welfare. Furthermore, sustainable usages of this plant wealth will support diversity which in profit elevation of native ecotourism initiatives.

Acknowledgement: The authors extend their appreciation to the Deanship of Scientific Research, King Khalid University for funding this work through research groups program under grant number R.G.P. 2/14/40. We are extremely thankful to the local community of district Faisalabad for sharing their indigenous information and data awareness about local medicinal plants.

Author's contribution: MAA, NI, MA, AN and AM conducted surveys travelled to field and written manuscript. NK and WI compiled and analyzed data. SA and $\mathrm{MH}$ edited manuscript and provided funds for this study.

Conflict of Interest: All the authors declared that there are no known conflicts of interest associated with this publication.

\section{REFERENCES}

Abdelhalim, A., T. Aburjai, J. Hanrahan, and H. AbdelHalim (2017). Medicinal plants used by traditional healers in Jordan, the Tafila region. Pharmacogn. Mag. 13 (1):S95. 
Ahmad, K. S., A. Hamid, F. Nawaz, M. Hameed, F. Ahmad, J. Deng, N. Akhtar, A. Wazarat and S. Mahroof (2017). Ethnopharmacological studies of indigenous plants in Kel village, Neelum Valley, Azad Kashmir, Pakistan. J. Ethonobio. Ethnomed. 13(1): 68.

Ahmad, M., M.P.Z. Khan, A. Mukhtar, M. Zafar, S. Sultana, and S. Jahan (2016). Ethnopharmacological survey on medicinal plants used in herbal drinks among the traditional communities of Pakistan. J. Ethnopharmacol. 184:154-186.

Ahmed, H.M. (2016). Ethnopharmacobotanical study on the medicinal plants used by herbalists in Sulaymaniyah Province, Kurdistan, Iraq. J. Ethonobio. Ethnomed. 12(1): 8.

Akram, M.A. (2020). COVID-19 Pandemic and Government Policies to Control its Situation in Pakistan. Acta Sci. Microbiol. 3: 164-170.

Alam, N., Z. Shinwari, M. Ilyas, and Z. Ullah (2011). Indigenous knowledge of medicinal plants of Chagharzai valley, District Buner, Pakistan. Pakistan J. Bot. 43 (2):773-780.

Albuquerque, U.P., R.F. Lucena, J.M. Monteiro, A.T. Florentino, and C. Cecília de Fátima (2006). Evaluating two quantitative ethnobotanical techniques. Ethnobot. Res. App. 4:051-060.

Alexiades, M.N., and J.W. Sheldon (1996). Selected guidelines for ethnobotanical research: a field manual. Advances in Economic Botany; Newyork (USA). 135p

Ali, A., L. Badshah, F. Hussain, and Z.K. Shinwari (2016). Floristic composition and ecological characteristics of plants of chail valley, district Swat, Pakistan. Pakistan J. Bot. 48 (3):10131026.

Ali, A., N. Akhtar, B.A. Khan, M.S. Khan, A. Rasul, N. Khalid, K. Waseem, T. Mahmood, and L. Ali (2012). Acacia nilotica: a plant of multipurpose medicinal uses. J. Med. Plants Res. 6(9):14921496.

Amirunnesa, S. K., K. Akter, S. Shipa and M. Rahmatullah (2018). Folk medicinal practices in Keraniganj Upazila, Dhaka district, Bangladesh. J. Med. Plants 6(1): 89-91.

Amjad, M.S., M. faisal Qaeem, I. Ahmad, S.U. Khan, S.K. Chaudhari, N.Z. Malik, H. Shaheen, and A.M. Khan (2017). Descriptive study of plant resources in the context of the ethnomedicinal relevance of indigenous flora: A case study from Toli Peer National Park, Azad Jammu and Kashmir, Pakistan. PLoS ONE 12 (2):e0171896.

Aqeel, M., A. Noman, T. Sanaullah, Z. Kabir, M. Buriro, N. Khalid, W. Islam, M. Qasim, M.U. Khan, A. Fida, S. Fida, M.A. Akram, and S.U.R. Sabir (2019). Characterization of genetically modified plants producing bioactive compounds for human health: a systemic review. Intl. J. Agric. Biol. 22(6): 1293-1304

Arulmozhi, S., P.M. Mazumder, P. Ashok, and S.L. Narayanan (2007). Pharmacological activities of Alstonia scholaris Linn. (Apocynaceae)-A review. Pharmacogn. Rev. 1 (1):163.

Ashraf, A., R.A. Sarfraz, M.A. Rashid, A. Mahmood, M. Shahid, and N. Noor (2016). Chemical composition, antioxidant, antitumor, anticancer and cytotoxic effects of Psidium guajava leaf extracts. Pharm. Biol. 54 (10):1971-1981.

Badgujar, S.B., V.V. Patel, A.H. Bandivdekar, and R.T. Mahajan (2014). Traditional uses, phytochemistry and pharmacology of Ficus carica: A review. Pharm. Biol. 52 (11):14871503.

Benarba, B. (2016). Medicinal plants used by traditional healers from South-West Algeria: An ethnobotanical study. J. Intercul. Ethnopharmacol. 5 (4):320.

Bhat, P., G.R. Hegde, G. Hegde, and G.S. Mulgund (2014). Ethnomedicinal plants to cure skin diseases-An account of the traditional knowledge in the coastal parts of Central Western Ghats, Karnataka, India. J. Ethnopharmacol., 151 (1):493-502.

Bibi, T., M. Ahmad, R.B. Tareen, N.M. Tareen, R. Jabeen, S.U. Rehman, S. Sultana, M. Zafar, and G. Yaseen (2014). Ethnobotany of medicinal plants in district Mastung of Balochistan province-Pakistan. J. Ethnopharmacol. 157:7989.

Chan, K., D. Shaw, M. S. Simmonds, C.J. Leon, Q. Xu, A. Lu, I. Sutherland, S. Ignatova, Y.-P. Zhu, and R. Verpoorte (2012). Good practice in reviewing and publishing studies on herbal medicine, with special emphasis on traditional Chinese medicine and Chinese materia medica. J. Ethnopharmacol. 140 (3):469-475.

Cheikhyoussef, A., M. Shapi, K. Matengu, and H.M. Ashekele (2011). Ethnobotanical study of indigenous knowledge on medicinal plant use by traditional healers in Oshikoto region, Namibia. J. Ethnobiol. Ethnomed. 7 (1):10.

Dayrit, F.M., A.D. Alcantar and I.M. Villasenor (1990). Studies on Moringa oleifera seeds. 1. The antibiotic compound and its deactivation in aqueous solution. Phil. J. Sci. 119(1): 23-32.

de Carvalho, M.C.R.D., F.N.T.V. Barca, L.F. AgnezLima and S.R.B. de Medeiros (2003). Evaluation of mutagenic activity in an extract of pepper tree stem bark (Schinus terebinthifolius Raddi). Environ. Mol. Mutagen. 42(3): 185-191.

Dolatkhahi, M., A. Dolatkhahi and J.B. Nejad (2014). Ethnobotanical study of medicinal plants used in 
Arjan-Parishan protected area in Fars Province of Iran. Avicenna J. Phytomed. 4(6): 402.

El-Ahmady, S.H., M.L. Ashour, and M. Wink (2013). Chemical composition and anti-inflammatory activity of the essential oils of Psidium guajava fruits and leaves. J. Essent. Oil Res. 25 (6):475481.

Elias, A., D. Seifu, F. Ashall, and T. Tolessa (2017). The Effect of ethanol Psidium Guava leaf extract on $\mathrm{KCl}$ Induced Contracted Aortic tissues of Guinea Pigs. J. Dis. Med. Plants 3 (1):7-11.

Farag, M., A. El Gamal, A. Kalil, A. Al-Rehaily, O. El Mirghany and K. El Tahir (2013). Evaluation of some biological activities of Albizia lebbeck flowers. Pharmacol. Pharm. 4(06): 473.

Farag, M., A. El Gamal, A. Kalil, A. Al-Rehaily, O. El Mirghany, and K. El Tahir (2013). Evaluation of some biological activities of Albizia lebbeck flowers. Pharmacol. Pharm. 4 (6):473.

Farzana, M., and I. Tharique (2014). A review of ethnomedicine, phytochemical and pharmacological activities of Acacia nilotica (Linn) willd. J. Pharmacog. Phytochem. 3 (1): 84-90

Friedman, J., Z. Yaniv, A. Dafni, and D. Palewitch (1986). A preliminary classification of the healing potential of medicinal plants, based on a rational analysis of an ethnopharmacological field survey among Bedouins in the Negev Desert, Israel. J. Ethnopharmacol. 16 (2-3):275287.

González-Tejero, M., M. Casares-Porcel, C. SánchezRojas, J. Ramiro-Gutiérrez, J. Molero-Mesa, A. Pieroni, M. Giusti, E. Censorii, C. De Pasquale, and A. Della (2008). Medicinal plants in the Mediterranean area: synthesis of the results of the project Rubia. J. Ethnopharmacol. 116 (2):341-357.

Greenham, J.R., R.J. Grayer, J.B. Harborne and V. Reynolds (2007). Intra-and interspecific variations in vacuolar flavonoids among Ficus species from the Budongo Forest, Uganda. Biochem. System. Eco. 35(2): 81-90.

Haq, F. (2012). The ethno botanical uses of medicinal plants of Allai Valley, Western Himalaya Pakistan. Int. J. Plant Res. 2(1): 21-34.

Heinrich, M., A. Ankli, B. Frei, C. Weimann, and O. Sticher (1998). Medicinal plants in Mexico: Healers' consensus and cultural importance. Soc. Sci. Med., 47 (11):1859-1871.

Hocking, G.M. (1958). Pakistan medicinal plants I. Qualitas Plantarum et Materiae Vegetabiles 5 (12):145-153.

Hussain, F., S. S. Shaukat, M. Abid, and F. Usman (2012). Some important medicinal plants associated with the vegetation in District
Mirpurkhas, Sindh. Int. J. Biol. Biotechnol. 9:405-420.

Hussain, M., M.S.A. Ahmed, M. Hameed, M. Aqeel, S. Rasool and A. Iftikhar (2012). Threats to rainfed and canal irrigated agro-ecosystems of the Punjab, Pakistan by weed infestation. Pakistan J. Bot. 44(SI): 171-178.

Ishtiaq, M., A. S. Mumtaz, T. Hussain, and A. Ghani (2012). Medicinal plant diversity in the flora of Leepa Valley, Muzaffarabad (AJK), Pakistan. Afri. J. Biotechnol. 11(13):3087-3098.

Islam, W., I. Nazir, A. Noman, M. Zaynab, and Z. Wu (2017). Inhibitory effect of different plant extracts on Trogoderma granarium (everts) (coleoptera: dermestidae). Int. J. Agri.Env. Res. 3(1): 121130.

Joseph, L., M. George, G. Singh, and P. Mathews (2016). Phytochemical investigation on various parts of Psidium guajava. Ann. Plant Sci. 5(2):12651268.

Joshi, K. (2003). Leaf flavonoid patterns in Dipterocarpus and Hopea (Dipterocarpaceae). Bot. J. Linnean Soc. 143(1): 43-46.

Kayani, S., M. Ahmad, S. Sultana, Z. K. Shinwari, M. Zafar, G. Yaseen, M. Hussain and T. Bibi (2015). Ethnobotany of medicinal plants among the communities of Alpine and Sub-alpine regions of Pakistan. J. Ethnopharmacol. 164: 186-202.

Khambay, B.P., D. Batty, M. Cahill, I. Denholm, M. Mead-Briggs, S. Vinall, H. M. Niemeyer and M. S. Simmonds (1999). Isolation, characterization, and biological activity of naphthoquinones from Calceolaria andina L. J. Agric. Food Chem. 47(2): 770-775.

Khan, M.P.Z., M. Ahmad, M. Zafar, S. Sultana, M.I. Ali, and H. Sun (2015). Ethnomedicinal uses of edible wild fruits (EWFs) in Swat Valley, Northern Pakistan. J. Ethnopharmacol. 173:191203.

Kibonde, S.F., S. Augustino, F. P. Mabiki and R. Mdegela (2018). Ethnobotanical study of medicinal plants used to manage HIV/AIDS opportunistic infections in Rungwe, Mbeya Region, Tanzania. J. Med. Plants Res. 12(2): 3241.

Lakhdari, W., A. Dehliz, F. Acheuk, R. Mlik, H. Hammi, B. Doumandji-Mitiche, S. Gheriani, M. Berrekbia, K. Guermit and S. Chergui (2016). Ethnobotanical study of some plants used in traditional medicine in the region of Oued Righ (Algerian Sahara). J. Med. Plants Res. 4(2): 204211

Leporatti, M., and E. Lattanzi (1994). Traditional phytotherapy on coastal areas of Makran (Southern Pakistan). Fitoterapia 65:158-161. 
Lin, R.J., C.Y. Chen and W.L. Lo (2008). Cytotoxic activity of Ipomoea cairica. Nat. Prod. Res. 22(9): 747-753.

Malla, B., D.P. Gauchan, and R.B. Chhetri (2015). An ethnobotanical study of medicinal plants used by ethnic people in Parbat district of western Nepal. J. Ethnopharmacol. 165:103-117.

Martin, G. J. (2010). Ethnobotany: a methods manual: Ist Ed. Routledge; London (UK). 224p

Maryo, M., S. Nemomissa and T. Bekele (2015). An ethnobotanical study of medicinal plants of the Kembatta ethnic group in Enset-based agricultural landscape of Kembatta Tembaro (KT) Zone, Southern Ethiopia. Asian J. Plant Sci. Res. 5(7): 42-61.

Mawa, S., K. Husain, and I. Jantan (2013). Ficus carica L. (Moraceae): phytochemistry, traditional uses and biological activities. Evid. Based Complement. Alternat. Med. 2013:974256

Mendez, D., A.M. Kutty, and S. Prasad (2016). Preferential inhibition of bacterial elastase over human neutrophil elastase by leaf extracts of Psidium guajava: an in vitro study. Nat. J. Physiol. Pharm. Pharmacol. 6 (2):123-127.

MH, A., and S. Hamdam (2017). Medicinal Plants Used Traditionally in Guldara District of Kabul, Afghanistan. Int. J. Pharmacogn. Chinese Med. 1(3):000118.

Mishra, S., V. Gothecha, and A. Sharma (2010). Albizia lebbeck: a short review. J. Herb. Med.Toxicol. 4 (2):9-15.

Musa, M.S., F.E. Abdelrasool, E. A. Elsheikh, L. A. Ahmed, A. L. E. Mahmoud, and S. M. Yagi (2011). Ethnobotanical study of medicinal plants in the Blue Nile State, South-eastern Sudan. J. Med. Plants Res. 5 (17):4287-4297.

Noman, A., I. Hussain, Q. Ali, M.A. Ashraf, and M.Z. Haider (2013). Ethnobotanical studies of potential wild medicinal plants of Ormara, Gawadar, Pakistan. Emir. J. Food Agric. 25 (10):751-759.

Noman, A., M. Aqeel, S. Khan, S. Anwer, and Q. Ali (2017). Exploration of medicinal phytodiversity at Makran coast; a realm of opportunities and challenges. Pakistan J. Bot. 42:177-190.

Panghal, M., V. Arya, S. Yadav, S. Kumar, and J.P. Yadav (2010). Indigenous knowledge of medicinal plants used by Saperas community of Khetawas, Jhajjar District, Haryana, India. J. Ethnobiol. Ethnomed. 6(1):4.

Phillips, O., and A.H. Gentry (1993). The useful plants of Tambopata, Peru: I. Statistical hypotheses tests with a new quantitative technique. Eco. Bot. 47 (1):15-32.

Qasim, M., Z. Abideen, M.Y. Adnan, R. Ansari, B. Gul, and M. Khan (2014). Traditional ethnobotanical uses of medicinal plants from coastal areas. J. Coastal Life Medic. 2 (1):22-30.

Revathi, P., T. Parimelazhagan, and S. Manian (2013). Ethnomedicinal plants and novel formulations used by Hooralis tribe in Sathyamangalam forests, Western Ghats of Tamil Nadu, India. J. Med. Plants Res. 7 (28):2083-2097.

Sarwat, S., and N. Ahmad (2012). Screening of potential medicinal plants from district sawat specific for controlling women diseases. Pakistan J. Bot. 44 (4):1193-1198.

Sasidhar, K., P. Brahmajirao and A. S. Kumar (2016). Ethnobotanical Studies on Medicinal Plant Utilization by the Yanadhi Tribe of Ananthasagaram Mandal, Nellore District, Andhra Pradesh, India. Int. Adv. Res. J. Sci. Eng. Technol., 3(3):75-80.

Šavikin, K., G. Zdunić, N. Menković, J. Živković, N. Ćujić, M. Tereščenko, and D. Bigović (2013). Ethnobotanical study on traditional use of medicinal plants in South-Western Serbia, Zlatibor district. J. Ethnopharmacol. 146 (3):803-810.

Shahat, A.A., N. M. Nazif, L. M. Abousetta, N. A. Ibrahim, P. Cos, S. V. Miert, L. Pieters and A. J. Vlietinck (2005). Phytochemical investigation and antioxidant activity of Duranta repens. Phytother. Res. 19(12): 1071-1073.

Sheyin, Z., J. Maimako, J. Shindang, C. Essien, E. Bigwan, and F. Ede (2015). Antimicrobial activity of Albizia lebbeck leaf extract on some medically important bacteria. Int. J. Curr. Microbiol. App. Sci. 4 (9):473-477.

Shinwari, M.I., and M.A. Khan (2000). Folk use of medicinal herbs of Margalla hills national park, Islamabad. J. Ethnopharmacol. 69 (1):45-56.

Shinwari, Z. K. (2010). Medicinal plants research in Pakistan. J. Med. Plants Res. 4 (3):161-176.

Shinwari, Z.K., and M. Qaiser (2011). Efforts on conservation and sustainable use of medicinal plants of Pakistan. Pakistan J. Bot. 43 (1):5-10.

Siddiqui, B.S., S. Tariq Ali and S. Kashif Ali (2006). A new flavanoid from the flowers of Azadirachta indica. Nat. Prod. Res. 20(3): 241-245.

Simao, A.A., T.R. Marques, S. Marcussi, and A.D. Correa (2017). Aqueous extract of Psidium guajava leaves: phenolic compounds and inhibitory potential on digestive enzymes. An. Acad. Bras. Cienc. 89 (3):2155-2165.

Teklehaymanot, T. (2009). Ethnobotanical study of knowledge and medicinal plants use by the people in Dek Island in Ethiopia. J. Ethnopharmacol. 124 (1):69-78.

Umair, M., M. Altaf, and A.M. Abbasi (2017). An ethnobotanical survey of indigenous medicinal 
plants in Hafizabad district, Punjab-Pakistan. PLoS ONE 12 (6):e0177912.

Verpoorte, R., A. Contin and J. Memelink (2002). Biotechnology for the production of plant secondary metabolites. Phytochem. Rev. 1(1): 13-25.

Vitalini, S., M. Iriti, C. Puricelli, D. Ciuchi, A. Segale, and G. Fico (2013). Traditional knowledge on medicinal and food plants used in Val San Giacomo (Sondrio, Italy)-An alpine ethnobotanical study. J. Ethnopharmacol. 145 (2):517-529.
Zahoor, M., Z. Yousaf, T. Aqsa, M. Haroon, N. Saleh, A. Aftab, S. Javed, M. Qadeer and H. Ramazan (2017). An ethnopharmacological evaluation of Navapind and Shahpur Virkanin district Sheikupura, Pakistan for their herbal medicines. J. Ethonobio. Ethnomed. 13(1): 27.

Zaman, S., and A. Hazrat (2013). Ethnobotanical survey of medicinal plants from tehsil Dargai, district Malakand, Pakistan. FUUAST J. Bio. 3(1): 109.

Zereen, A., Z.U.D. Khan, and A.A. Sardar (2013). Ethnobotanical studies of wild herbs of central Punjab, Pakistan. Bangladesh J. Plant Taxono. 20(1): 67-76. 